\title{
Remotely sensing phytoplankton size structure in the Red Sea
}

\author{
John A. Gittings ${ }^{\mathrm{a}, *}$, Robert J.W. Brewin ${ }^{\mathrm{b}, \mathrm{c}}$, Dionysios E. Raitsos ${ }^{\mathrm{c}, \mathrm{d}}$, Malika Kheireddine ${ }^{\mathrm{e}}$, \\ Mustapha Ouhssain $^{\mathrm{e}}$, Burton H. Jones ${ }^{\mathrm{e}}$, Ibrahim Hoteit ${ }^{\mathrm{a}}$ \\ ${ }^{a}$ King Abdullah University of Science and Technology (KAUST), Department of Earth Science and Engineering, Thuwal 23955-6900, Saudi Arabia \\ ${ }^{\mathrm{b}}$ College of Life and Environmental Sciences, University of Exeter, Penryn Campus, Penryn TR10 9FE, United Kingdom \\ ${ }^{\mathrm{c}}$ Plymouth Marine Laboratory (PML), The Hoe, Plymouth PL1 3DH, United Kingdom \\ ${ }^{\mathrm{d}}$ Department of Biology, National and Kapodistrian University of Athens, Athens, Greece \\ ${ }^{\mathrm{e}}$ King Abdullah University of Science and Technology (KAUST), Red Sea Research Center, Biological and Environmental Science and Engineering Division, Thuwal 23955- \\ 6900, Saudi Arabia
}

\section{A R T I C L E I N F O}

\section{Keywords:}

Ocean colour

Remote sensing

Phytoplankton

Size structure

Chlorophyll

Red Sea

\begin{abstract}
A B S T R A C T
Phytoplankton size structure impacts ocean food-web dynamics and biogeochemical cycling, and is thus an important ecological indicator that can be utilised to quantitatively evaluate the state of marine ecosystems. Potential alterations to size structure are predicted to occur in tropical regions under future scenarios of climate change. Therefore, there is an increasing requirement for the synoptic monitoring of phytoplankton size structure in marine systems. The Red Sea remains a comparatively unexplored tropical marine ecosystem, particularly with regards to its large-scale biological dynamics. Using an in situ pigment dataset acquired in the Red Sea, we parameterise a two-component, abundance-based phytoplankton size model and apply it to remotely-sensed observations of chlorophyll-a (Chl-a) concentration, to infer Chl-a in two size classes of phytoplankton, small cells $<2 \mu \mathrm{m}$ in size (picophytoplankton) and large cells $>2 \mu \mathrm{m}$ in size. Satellite-derived estimates of phytoplankton size structure are in good agreement with corresponding in situ measurements and also capture the spatial variability related to regional mesoscale dynamics. Our analysis reveals that, for the estimation of Chl-a in the two size classes, the model performs comparably or in some cases better, to validations in other oceanic regions. Our model parameterisation will be useful for future studies on the seasonal and interannual variability of phytoplankton size classes in the Red Sea, which may ultimately be relevant for understanding trophic linkages between phytoplankton size structure and fisheries, and the development of marine management strategies.
\end{abstract}

\section{Introduction}

Ecological indicators, which may be defined as quantifiable metrics that characterise ecosystem structure, composition or function, can be used to monitor the state of marine ecosystems and their response to environmental perturbations (Niemi and McDonald, 2004; Platt and Sathyendranath, 2008; Racault et al. 2014). In the global oceans, commonly used indicators are typically based on the presence and distribution of phytoplankton (as indexed by the concentration of chlorophyll-a [Chl-a]), which form the base of oceanic food webs. Among the ecological indicators that can be derived from observations of ocean colour (e.g. primary production and phytoplankton phenology), the size structure of phytoplankton communities is particularly important as it can influence marine food web structure (Legendre and Le Fevre, 1991; Moloney and Field, 1991; Parsons and Lalli, 2002), biogeochemical cycling (Chisholm, 1992), carbon export (Boyd and Newton, 1999; Briggs et al., 2011; Eppley and Peterson, 1979; Guidi et al., 2009; Laws et al., 2000; McCave, 1975) and the thermal structure of the upper-oceanic layer (Sathyendranath and Platt, 2007).

The Red Sea, situated between the African continent and Arabian Peninsula, is the world's northernmost tropical sea. It hosts coral reef ecosystems, contains high levels of marine biodiversity, and supports shipping, fisheries and tourism, making it a vital economic asset to the region (Berumen et al., 2013; Carvalho et al., 2018; Gladstone et al., 2013). Over the last decade, the Red Sea has been subject to regional warming (Chaidez et al., 2017; Krokos et al., 2019; Raitsos et al., 2011), linked with coral reef bleaching events (Cantin et al., 2010; Monroe et al., 2018; Osman et al., 2018), and alterations in phytoplankton abundance and phenology (Gittings et al., 2018; Raitsos et al., 2015). Consequently, there is a need to monitor the response of the Red Sea

\footnotetext{
* Corresponding author.

E-mail address: john.gittings@kaust.edu.sa (J.A. Gittings).
} 


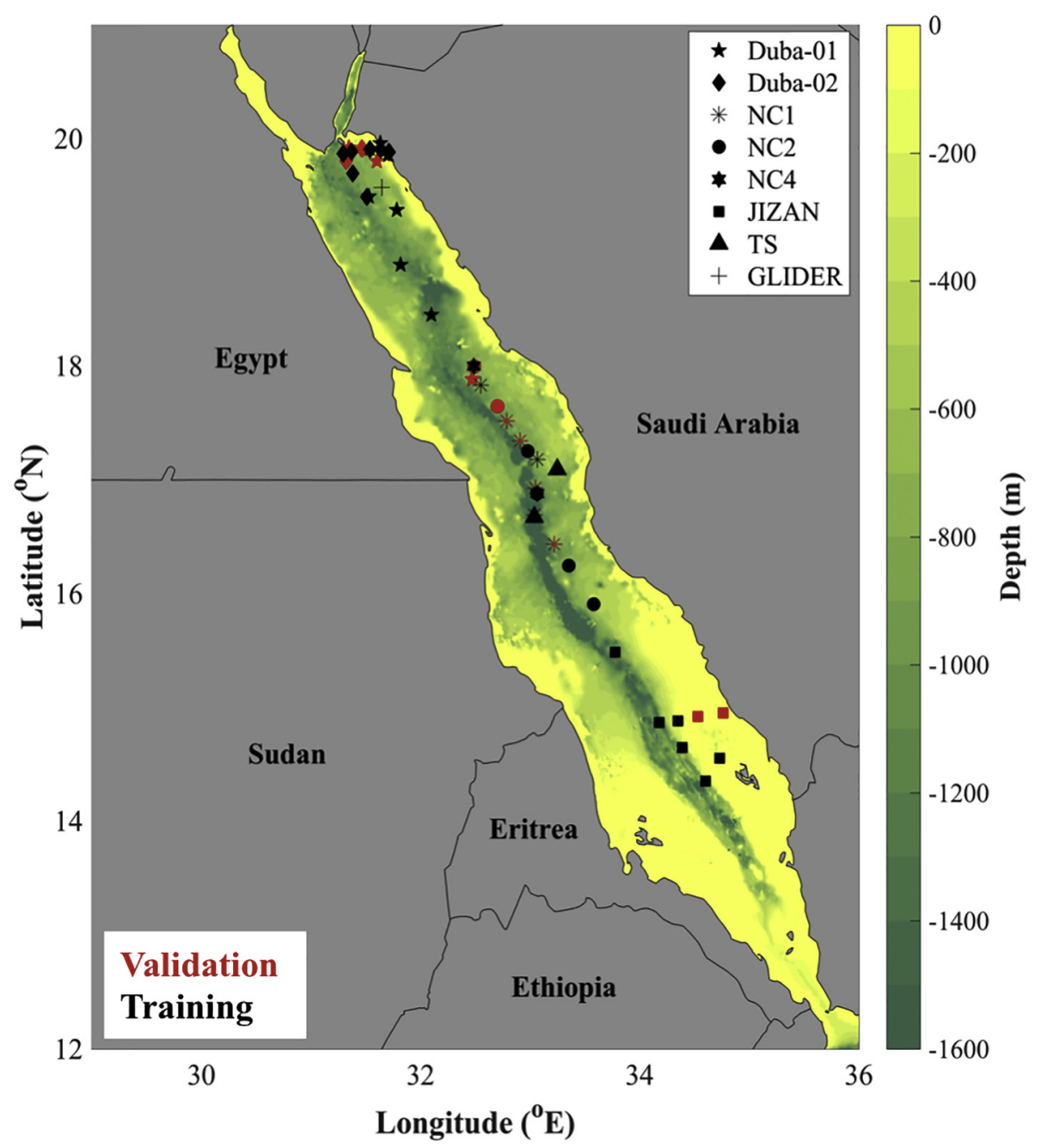

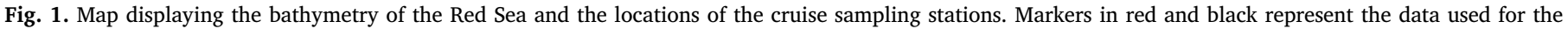

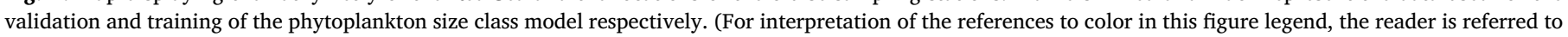
the web version of this article.)

ecosystem to future climate variability.

Due to limited in situ sampling, knowledge on the spatiotemporal distribution of phytoplankton size structure in the Red Sea is relatively sparse. Nevertheless, increased in situ sampling efforts over the last two decades have enabled researchers to gain insight in localised regions of the Red Sea, including the Gulf of Aqaba (Shaikh et al., 1986; Sommer et al., 2002), the central east coast (Al-Najjar et al., 2007; Touliabah et al., 2010) and the north-western Red Sea (Nassar et al., 2014). More recently, Pearman et al. (2016) used a molecular approach to assess phytoplankton community structure in the northern and southern ends of the Red Sea, and Kheireddine et al. (2017) used a taxonomic, pigment-based approach to investigate community structure along the central axis of the basin. Both studies revealed that pico-phytoplankton were the main contributor to the total phytoplankton biomass, although the relative contributions of pico-, nano- and micro-phytoplankton varied with environmental conditions and mesoscale features. For extensive reviews on phytoplankton species composition in the Red Sea, the reader is referred to the works of Ismael (2015) and Qurban et al. (2019).

A key method used to observe ecological indicators synoptically and frequently is ocean-colour remote sensing (Platt and Sathyendranath, 2008, Platt et al., 2009), and several studies have demonstrated the applicability of satellite remote sensing for investigating the spatiotemporal distribution of phytoplankton abundance in the Red Sea (Acker et al., 2008; Brewin et al., 2013, 2015a; Dreano et al., 2016;
Gittings et al., 2018, 2019; Papadopoulos et al., 2015; Racault et al., 2015; Raitsos et al., 2013, 2015, 2017; Triantafyllou et al., 2014). Existing remote-sensing methodologies for deriving phytoplankton size classes (PSCs) can be broadly categorised into abundance-based (Brewin et al., 2010, 2011; Hirata et al., 2011; Uitz et al., 2006) and spectral-based (Devred et al., 2011; Kostadinov et al., 2009) approaches. A detailed review of these different methods can be found in Sathyendranath et al. (2014), Bracher et al. (2017) and Mouw et al. (2017). Recent inter-comparisons have revealed that abundance-based approaches, which exploit the ubiquitous relationship between phytoplankton biomass and cell size (lower biomass equates to smaller cell size and vice versa, (Chisholm, 1992)), performs well at retrieving PSCs (Hu et al., 2018; Liu et al., 2018). Specifically, the three-component PSC model of Brewin et al. (2010), which builds upon the work of Sathyendranath et al. (2001) and Devred et al. (2006), was shown to perform well in these inter-comparisons, and has been successfully reparameterised and validated in many other oceanic regions, including: the Atlantic Ocean (Brewin et al., 2010; Brotas et al., 2013), the Indian Ocean (Brewin et al., 2012a), the South China Sea (Lin et al., 2014), the continental shelf seas of China (Sun et al., 2018), the Western Iberian coastline (Brito et al., 2015), the Mediterranean Sea (Sammartino et al., 2015), Southern Africa (Lamont et al., 2018), Chile (Corredor-Acosta et al., 2018) and the global ocean (Brewin et al., 2015b; Ward, 2015).

Recently, Brewin et al. (2015a) applied this model to derive pico$(<2 \mu \mathrm{m})$ and combined nano/micro- $(>2 \mu \mathrm{m})$ phytoplankton size 
classes in the Red Sea. However, due to the paucity of in situ data on these two size classes within the region, at the time, their study utilised model parameters obtained from other oceanic regions (see Brotas et al., 2013), justified through analysis of particulate absorption data collected in the Red Sea. Since then, in situ datasets have become available, enabling the characterisation of phytoplankton size structure in the Red Sea over large spatial scales (Kheireddine et al., 2017, 2018a). In this study, we utilise these newly available datasets to test and subsequently re-parameterise the PSC model of Brewin et al. (2015a) for the first time in the Red Sea. We then apply this model to ocean-colour observations and provide a series of examples demonstrating the improved performance of the updated approach.

\section{Data and methodology}

\subsection{Oceanographic cruises and sampling}

Seawater samples were acquired during five research cruises conducted across the Red Sea between October 2014 and January 2016 aboard the $R / V$ Thuwal (Kheireddine et al., 2017, 2018a) (Fig. 1, Table 1). Collectively, these cruises spanned the majority of the Red Sea (latitudinal range of $\sim 15^{\circ} \mathrm{N}-27^{\circ} \mathrm{N}$ ) and, for convenience, can be separated into the following biogeographical regions: the Northern Red Sea (NRS), Central Red Sea (CRS) and Southern Red Sea (SRS).

A total of 49 stations were sampled over the Red Sea, although we note that two of these stations were repeated locations sampled on different days. The biogeographic region and temporal period associated with each of the cruises is presented in Table 1 and described in further detail by Kheireddine et al. (2018a).

\subsection{Phytoplankton pigment database}

Briefly, at each sampling station, seawater samples (volume ranging from 2.4 to $2.8 \mathrm{~L}$ ) were collected within the upper $200 \mathrm{~m}$ of the water column and filtered through $25 \mathrm{~mm}$ diameter Whatman GF/F filters (porosity of $0.7 \mu \mathrm{m}$ ). The filters were flash frozen and stored in liquid nitrogen throughout the cruise, then transferred to an $-80^{\circ} \mathrm{C}$ freezer in the laboratory prior to analysis. Samples were extracted in $3 \mathrm{~mL}$ of $100 \%$ methanol, disturbed with glass pearls on a cooled vibratory homogenizer, centrifuged, and filtered $2 \mathrm{~h}$ later using a Teflon syringe filter $(0.2 \mu \mathrm{m})$. Within $24 \mathrm{~h}$, the sample extracts were analysed by High Performance Liquid Chromatography (HPLC) using a complete 1260 Agilent Technologies system. Measurements of photosynthetic phytoplankton pigments were acquired in accordance with the HPLC analytical procedure followed by Ras et al. (2008) and as described by Kheireddine et al. (2017, 2018a). Only samples within the upper $20 \mathrm{~m}$ of the water column for each station were selected for the analysis, as satellite sensors acquire measurements approximately within the first optical depth (typically around $20 \mathrm{~m}$ in the Red Sea (Raitsos et al., 2013)). Uncertainties associated with the determination of pigment concentrations were calculated using the principles of uncertainty propagation and are provided in Kheireddine et al. (2017).

\subsection{Estimation of phytoplankton size structure from HPLC data}

For estimating phytoplankton size fractions from HPLC data, we used the method of Brewin et al. (2015b), adapted from Claustre (1994), Vidussi et al. (2001), Uitz et al. (2006), Brewin et al. (2010) and Devred et al. (2011). First, the total Chl-a concentration (C) was computed from the weighted sum of seven diagnostic phytoplankton pigments (henceforth referred to as $C_{w}$ ), according to.

$C_{w}=\sum_{i=1}^{7} W_{i} P_{i}$

where $\mathbf{W}$ represents the weights and $\mathbf{P}$ corresponds to the following 
Table 2

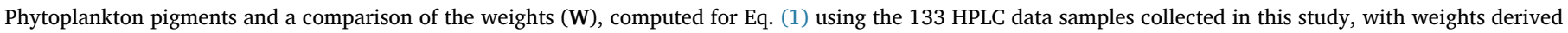
from other studies.

\begin{tabular}{|c|c|c|c|c|c|c|c|}
\hline Pigment & This study & Brewin et al. (2014a) & Brewin et al. (2015b) & Brewin et al. (2017a) & Uitz et al. (2006) & Uitz et al. (2008) & Soppa et al. (2014) \\
\hline Fucoxanthin & $1.18( \pm 0.51)$ & 1.72 & 1.51 & 1.65 & 1.41 & 1.65 & 1.55 \\
\hline Peridinin & $6.45( \pm 2.60)$ & 1.27 & 1.35 & 1.04 & 1.41 & 1.3 & 0.41 \\
\hline 19' - Hexanoyloxyfucoxanthin & $0.57( \pm 0.61)$ & 0.68 & 0.95 & 0.78 & 1.27 & 0.83 & 0.86 \\
\hline 19' - Butanoyloxyfucoxanthin & $3.15( \pm 1.51)$ & 1.42 & 0.85 & 1.19 & 0.35 & 0.78 & 1.17 \\
\hline Alloxanthin & $7.70( \pm 3.37)$ & 4.96 & 2.71 & 3.14 & 0.6 & 0.73 & 2.39 \\
\hline Total chlorophyll-b & $1.66( \pm 0.57)$ & 0.81 & 1.27 & 1.38 & 1.01 & 0.77 & 1.06 \\
\hline Zeaxanthin & $0.72( \pm 0.13)$ & 1.28 & 0.93 & 1.02 & 0.86 & 1.29 & 2.04 \\
\hline
\end{tabular}

seven diagnostic pigments: fucoxanthin, peridinin, 19'-hexanoyloxyfucoxanthin, 19'-butanoyloxyfucoxanthin, alloxanthin, total chlorophyll-b and zeaxanthin. We estimated $\mathbf{W}$ by applying a multi-linear regression on the 133 samples collected during the five cruises. We then compared our weights with previous studies conducted in other regions of the global oceans (Table 2). The computed weights are in reasonable agreement with other datasets, with the exception of notable differences observed for the weights attributed to peridinin and alloxanthin. We speculate that the differences in these particular pigments were related to their very low concentrations during sampling. As only a small number of samples (133) were used to compute the weights, when compared with other published studies (e.g. Uitz et al., 2006; Brewin et al., 2015b), and considering the potentially erroneous values obtained with the re-parameterisation, we also tested weights derived from multiple studies across different regions (Table 2). Excluding our own re-parameterised weights, the weights computed by Brewin et al. (2014a) gave the overall best statistical performance with regards to the relationship between $C_{w}$ and total Chl-a (C) (Supplementary Fig. 1). Accordingly, we used these weights in our analysis.

Next, based on the previously reported finding that two opticallydistinct assemblages of particles dominate the Red Sea, and that Chl-a in the Red Sea is generally lower than $1 \mathrm{mg} \mathrm{m}^{-3}$ (Brewin et al., 2015a), we computed fractions of the total Chl-a concentration for two size classes: pico-phytoplankton (cell size $<2 \mu \mathrm{m}$ ) and combined nano/ micro-phytoplankton (cell size $>2 \mu \mathrm{m}$ ). Due to a low contribution of micro-phytoplankton to total Chl-a in our dataset (figure not shown), a two-component model was selected for our study as a more parsimonious solution to the original three-component model put forth by Brewin et al. (2010). However, we do not rule out the future use of a three-component model in the region, should datasets become available that span a higher range of chlorophyll (e.g. in coastal waters). Following Eq. (2), the fraction of pico-phytoplankton $\left(F_{p}\right)$ was computed using zeaxanthin, total chlorophyll-b and by apportioning some of 19hexanoyloxyfucoxanthin to the pico-phytoplankton pool at total Chl-a concentrations $<0.08 \mathrm{mg} \mathrm{m}^{-3}$ (Brewin et al., 2010, 2015b)

$F_{p}=\left\{\begin{array}{c}\frac{(-12.5 C+1) W_{3} P_{3}}{C_{w}}+\frac{\sum_{i=6}^{7} W_{i} P_{i}}{C_{w}} \text { if } \mathrm{C} \leq 0.08 \mathrm{mg} \mathrm{m}^{-3} \\ \frac{\sum_{i=6}^{7} W_{i} P_{i}}{C_{w}} \text { if } \mathrm{C} \geq 0.08 \mathrm{mg} \mathrm{m}^{-3}\end{array}\right.$

The fraction of Chl-a attributed to the combined nano/micro phytoplankton assemblage $\left(F_{n, m}\right)$ was then computed as

$F_{n, m}=1-F_{p}$

After deriving the fractions of the picophytoplankton $\left(F_{p}\right)$ and combined nano/micro $\left(F_{n, m}\right)$ phytoplankton populations relative to total Chl-a, the Chl-a concentration attributed to the two size classes was calculated as

$C_{p}=F_{p} C$

and

$C_{n, m}=F_{n, m} C$ where $C_{p}$ and $C_{n, m}$ correspond to the size-specific Chl-a concentration of pico-phytoplankton and the combined nano/micro-phytoplankton respectively, and $C$ refers to the total Chl-a concentration.

\subsection{Datasets and data partitioning for training, satellite validation and visualisation}

The in situ samples were matched with estimates of satellite-derived remote sensing reflectance $\left(\mathrm{R}_{\mathrm{rs}}\right)$ from version 3.1 of the European Space Agency's Ocean Colour Climate Change Initiative product (OC-CCI). For the period spanning 2015-2017, the OC-CCI product consists of merged and bias-corrected data from the Moderate Resolution Imaging Spectroradiometer (MODIS) and Visible Infrared Imaging Radiometer Suite (VIIRS) satellite sensors. Level 3, daily, mapped data were acquired at a spatial resolution of $4 \mathrm{~km}$ from http://www.esaoceancolour-cci.org for the time periods corresponding to each of the cruises (Table 1). For further information, the reader is referred to previous literature regarding the OC-CCI product (Sathyendranath et al., 2012, 2016) and its previous applications in the Red Sea and adjacent Arabian Sea (Racault et al., 2015; Brewin et al., 2015a; Dreano et al., 2016; Gittings et al., 2017). In addition, we refer the reader to the OC-CCI Product User Guide at http://www.esa-oceancolour-cci.org/? $\mathrm{q}=$ webfm_send $/ 318$ for a more extensive overview of processing, sensor merging and uncertainty quantification. Each sample was matched to an individual satellite pixel temporally (same day) and spatially (nearest pixel based on longitude and latitude). Of the total 49 stations, we retrieved 14 satellite matchups. The corresponding sample stations for the matchups were set aside for the independent validation of satellite-derived total Chl-a, size fractions and size-specific Chl-a (Fig. 1). The in situ samples at each of the matchup stations were averaged within the top $20 \mathrm{~m}$ (approximately the first optical depth). The remaining 35 in situ sampling stations were used for the development and re-parameterisation of the phytoplankton size model. We note that the remaining 35 sampling stations are representative of samples acquired at multiple depths (up to $20 \mathrm{~m}$ ). Thus, a total of 89 samples (corresponding to the remaining 35 stations) were used for the model reparameterisation.

We utilised three different empirical, satellite ocean-colour algorithms in our analysis: the standard OC-CCI algorithm (which is a blended combination of the OC5 (Gohin et al., 2002) and the OC4v6 OCI (Hu et al., 2012) algorithms) and the OC4 and OCI algorithms (Hu et al., 2012; O'Reilly et al., 2000) that have been regionally tuned for the Red Sea by Brewin et al. (2015a) (hereafter referred to as OC4-RG and OCI-RG respectively, Fig. 2). For further illustrative and qualitative validation of the phytoplankton size model, daily images of satellitederived phytoplankton size fractions from the OC-CCI product were also extracted for periods coinciding with the timing of in situ sample collection during the cruise programs (Table 1).

In addition, to provide an example highlighting the potential of new remote-sensing technologies and their application for mapping PSCs, we used a Chl-a dataset acquired from the Ocean and Land Colour Instrument (OLCI) on-board the recently launched Sentinel-3a satellite of the European Space Agency. An 8-day composite image for the 

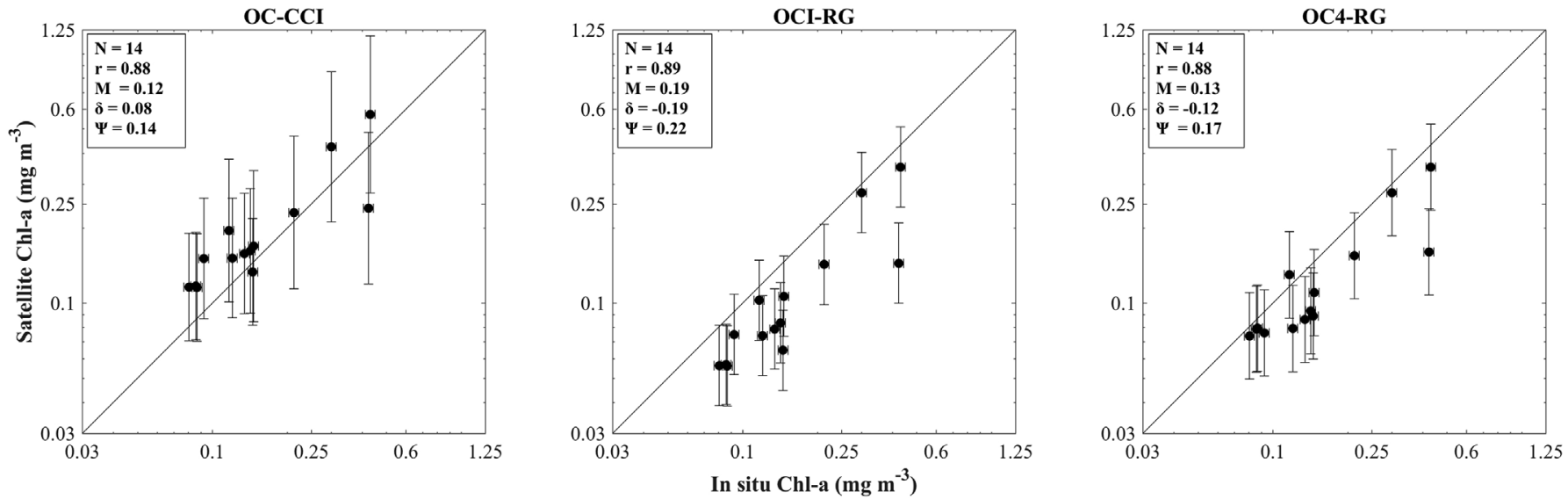

Fig. 2. Satellite validation of total Chl-a concentration from three different empirical ocean colour algorithms; the standard OC-CCI algorithm and the regionally

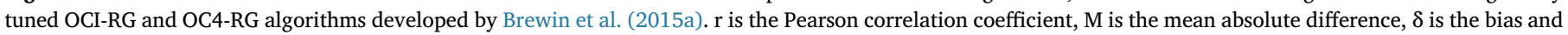

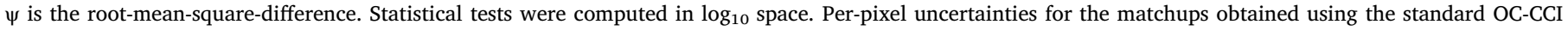

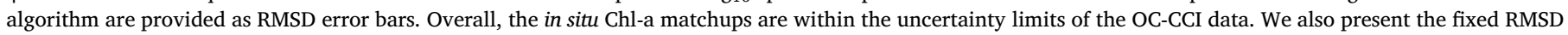

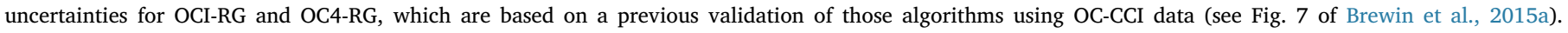
Uncertainties associated with in situ Chl-a concentrations are expressed as percentages $(\sim \pm 4.6 \%)$ and are represented by the black horizontal error bars.

period 28th February 2017-7th March 2017 was downloaded from the European Space Agency Copernicus Open Access Hub. This dataset has a spatial resolution of $300 \mathrm{~m}$ and was processed for the Red Sea using the regionally tuned algorithm developed by Brewin et al. (2015a).

\subsection{Two-component phytoplankton size class model}

Following Brewin et al. (2015a), we used a two-component size class model to characterise the pico-phytoplankton and combined nano/micro-phytoplankton assemblages in the Red Sea. The model assumes small phytoplankton cells (picophytoplankton) are incapable of growing beyond a specific Chl-a concentration, and the addition of extra Chl-a into the system beyond this concentration can be attributed to the addition of larger phytoplankton cells (Chisholm, 1992; Raimbault, 1988). The model is based on the exponential equation originally put forth by Sathyendranath et al. (2001) and used by Brewin et al. (2010) to relate the concentration of Chl-a in pico-phytoplankton $\left(C_{p}\right.$, cells $\left.<2 \mu \mathrm{m}\right)$ to the total Chl-a according to.

$C_{p}=C_{p}^{m}\left[1-\exp \left(-\frac{D_{p}}{C_{p}^{m}} C\right)\right]$

The parameter $C_{p}{ }^{m}$ represents the asymptotic maximum value of Chl-a associated with the pico-phytoplankton size class, whilst $D_{p}$ determines the fraction of total Chl-a for the picophytoplankton assemblage as total Chl-a $(C)$ tends to zero. The size-specific Chl-a concentration of the combined nano/micro-phytoplankton assemblage $\left(C_{n, m}\right)$ can subsequently be derived according to.

$C_{n, m}=C-C_{p}$

The model parameters $C_{p}{ }^{m}$ and $D_{p}$ were estimated by fitting Eq. (6) to the parameters $C_{p}$ and $C$, which were computed using the HPLC dataset. We used a non-linear, least squares fitting procedure (TrustRegion-Reflective algorithm, MATLAB Optimisation Toolbox, function 'LSQCURVEFIT'), in conjunction with bootstrapping (Efron, 1979), to compute the model parameters and their associated uncertainties (Table 3). Bootstrapping was implemented by randomly sub-sampling the dataset (1000 iterations) and re-fitting Eq. (6) for each sub-sample. The median and $95 \%$ confidence intervals were then computed from the resulting parameter distribution. The parameter $D_{p}$ was constrained to be less than or equal to 1 , as size-fractionated Chl-a cannot exceed the total Chl-a concentration. The model parameters are presented in Table 3 and generally appear to lie within the range of values that have been computed for different regions of the global oceans.

\subsection{Statistical tests}

For the assessment of satellite ocean-colour data and the validation of the re-parameterised model, we primarily used the Pearson linear correlation coefficient (r), mean absolute difference (MAD (M)) and bias $(\delta)$ as performance metrics to compare in situ and modelled values of total Chl-a, size fractions and size-specific Chl-a. The MAD is suggested to be less sensitive to different dataset distributions and the presence of outliers, and provides a natural and unambiguous characterisation of model uncertainty (Willmott and Matsuura, 2005). The MAD has been extensively utilised in other studies that involve comparisons between in situ and satellite estimates of chlorophyll (e.g. Moses et al., 2012; O'Reilly and Werdell, 2019) and phytoplankton size structure (e.g. Brewin et al., 2012a; Corredor-Acosta et al., 2018). The root-mean-square-difference (RMSD, $\psi$ ) is also presented in order to allow comparisons of the model performance with previous studies. We note that the linear correlation coefficient and RMSD have previously been utilised to compare in situ and modelled data (Brewin et al., 2015c; Brewin et al., 2016; Doney et al., 2009; Friedrichs et al., 2009). Statistical tests based on Chl-a concentrations were conducted in $\log _{10}$ space, as Chl-a tends to be log-normally distributed in the open ocean (Campbell, 1995). The MAD (M) was computed according to.

$M=\frac{\sum_{i=1}^{N}\left|X_{i}^{E}-X_{i}^{M}\right|}{N}$

where $\mathrm{N}$ is the number of data points, $\mathrm{X}$ is the variable (total Chl-a concentration, size fraction or size-specific Chl-a) and the superscripts $\mathrm{E}$ and $\mathrm{M}$ correspond to the estimated variable from the model and the measured variable, respectively. The value of $\delta$ was calculated according to

$\delta=\frac{1}{N}\left[\sum_{i=1}^{N}\left(X_{i}^{E}-X_{i}^{M}\right)\right]$

and $\psi$ was expressed as

$\psi=\left[\frac{1}{N} \sum_{i=1}^{N}\left(X_{i}^{E}-X_{i}^{M}\right)^{2}\right]^{1 / 2}$ 
Table 3

Model parameters derived from Eq. (6) and comparisons with different studies.

\begin{tabular}{|c|c|c|c|c|c|}
\hline \multirow[t]{2}{*}{ Study } & \multicolumn{2}{|l|}{ Model parameters } & \multirow[t]{2}{*}{ Location } & \multirow[t]{2}{*}{$\mathrm{N}$} & \multirow[t]{2}{*}{ Method } \\
\hline & $C_{p}^{m}\left(m g m^{-} 3\right)$ & $D_{p}$ & & & \\
\hline This study & $0.19(0.16-0.23)$ & $0.92(0.85-1.0)$ & Red Sea & 89 & HPLC \\
\hline Brewin et al. (2012a) & 0.17 & 0.82 & Indian Ocean & 686 & HPLC \\
\hline Brewin et al. (2011) & 0.15 & 0.75 & Global & 256 & HPLC \\
\hline Brewin et al. (2015b) & $0.13(0.12-0.14)$ & $0.80(0.78-0.82)$ & Global & 5841 & HPLC \\
\hline Brewin et al. (2010) & 0.11 & 0.73 & Atlantic Ocean & 1935 & HPLC \\
\hline Brotas et al. (2013) & 0.06 & 0.99 & NE Atlantic Ocean & 1100 & HPLC \\
\hline Brewin et al. (2017a) & $0.13(0.12-0.13)$ & $0.73(0.71-0.76)$ & N Atlantic Ocean & 2239 & HPLC/SFF \\
\hline
\end{tabular}

Table 4

Statistical results for the three ocean colour algorithms used in this study, and some comparisons with previous studies.

\begin{tabular}{|c|c|c|c|c|c|c|c|}
\hline Study & Satellite dataset & Algorithm & $\mathrm{r}$ & $\Psi$ & M & $\mathrm{N}$ & Region \\
\hline This study & OC-CCI V3.1 & OC5/OC4v6-OCI & 0.88 & 0.14 & 0.12 & 14 & Red Sea \\
\hline This study & OC-CCI V3.1 & OCI-RG & 0.89 & 0.22 & 0.19 & 14 & Red Sea \\
\hline This study & OC-CCI V3.1 & OC4-RG & 0.88 & 0.17 & 0.13 & 14 & Red Sea \\
\hline Brewin et al. (2013) & MODIS-Aqua & OC3 & 0.69 & 0.2 & - & 85 & Red Sea \\
\hline Brewin et al. (2013) & MODIS-Aqua & OCI & 0.56 & 0.13 & - & 85 & Red Sea \\
\hline Brewin et al. (2015a) & OC-CCI V1 & OCI-RG & 0.87 & 0.16 & - & 410 & Red Sea \\
\hline Brewin et al. (2015a) & OC-CCI V1 & OC4-RG & 0.83 & 0.17 & - & 410 & Red Sea \\
\hline Racault et al. (2015) & OC-CCI V1 & OC4 & 0.84 & 0.29 & - & 392 & Red Sea \\
\hline Brewin et al. (2012a) & SeaWiFS & OC4 & 0.89 & - & 0.06 & 26 & Indian Ocean \\
\hline Lamont et al. (2018) & MODIS-Aqua & OCI & 0.98 & 0.14 & - & 33 & Southern Africa \\
\hline Bailey and Werdell (2006) & SeaWiFS & OC4 & 0.91 & 0.41 & - & 271 & Global \\
\hline Siegel et al. (2013) & SeaWiFS & GSM & 0.88 & 0.36 & - & 1380 & Global \\
\hline Siegel et al. (2013) & SeaWiFS & OC4 & 0.89 & 0.31 & - & 1543 & Global \\
\hline Brewin et al. (2015b) & OC-CCI V1 & OC4 & 0.88 & 0.25 & - & 598 & Global \\
\hline
\end{tabular}

\section{Results and discussion}

\subsection{Satellite validation of total Chl-a}

To determine the best input of Chl-a for the phytoplankton size model, we first evaluate the performance of three different ocean colour algorithms (Fig. 2, Table 4). Irrespective of the type of algorithm, in situ values of Chl-a concentration are in good agreement with the satellite matchups and the relationships are characterised by high correlation coefficients $(r>0.88)$ and low mean absolute differences $(\mathrm{M}<0.2)$. Using the correlation coefficient and RMSD $(\psi)$ as a basis for comparison with previous studies, the model performance is similar, or in some cases better, to what has been previously observed in the Red Sea (Brewin et al., 2013, 2015a; Racault et al., 2015) and other regions of the global ocean (e.g. Bailey and Werdell, 2006; Brewin et al., 2015b; Siegel et al., 2013) (Table 4).

Although the three algorithms exhibit a statistically similar performance (e.g. statistically similar values for the MAD (M) and RMSD ( $\psi)$ (95\% confidence intervals overlap) and a statistically similar correlation coefficient (z-test)), the standard OC-CCI algorithm overestimates Chl-a concentration $(\delta=0.08)$. This is analogous with the results of Brewin et al. (2015a) who found that the standard NASA OC4 and OCI algorithms systematically overestimate Chl-a in the Red Sea. They attributed this overestimation to increased chromophoric dissolved organic matter (CDOM) absorption per unit Chl-a. This hypothesis was recently corroborated by Kheireddine et al. (2018b), who analysed the spatial distribution of the absorption coefficient of CDOM ( $\mathrm{a}_{\mathrm{CDOM}}$ ), using in situ measurements acquired during several cruises conducted in the Red Sea. Kheireddine et al. (2018b) observed that values of $\mathrm{a}_{\mathrm{CDOM}}$ for a specific Chl-a concentration were substantially higher in the Red Sea in comparison to the adjacent Mediterranean Sea (20-550\%) (Organelli et al., 2014). The authors also revealed that CDOM concentrations were higher than what has been observed in other oligotrophic regions, such as the southeast Pacific and Mediterranean Sea (Bricaud et al., 2010; Morel and Gentili, 2009).
The regionally tuned OCI-RG and OC4-RG algorithms are associated with negative biases ( $\delta=-0.19$ and -0.12 respectively), particularly the OCI-RG algorithm, which displays a consistent underestimation of Chl-a (Fig. 2). However, considering the improved performance of the regionally-tuned Red Sea algorithms previously obtained using a larger match-up dataset (Brewin et al., 2015a), and it's slightly higher statistical performance in comparison to OCI-RG, we opted to use the OC4$\mathrm{RG}$ algorithm for input to the PSC model. On-going research is required to monitor the performance of all these algorithms, as and when more data become available in the Red Sea.

\subsection{Re-parameterisation of the two-component phytoplankton size model}

The re-parameterised size model was fitted to the Red Sea HPLC dataset (Fig. 3, black line), and for comparison, was plotted alongside the previous two-component model of Brewin et al. (2015a) (Fig. 3, red line). Overall, the re-parameterised model adequately captures the general trends in in situ derived size-specific Chl-a $\left(C_{p}, C_{n, m}\right)$ as a function of total Chl-a $(r>0.9, \mathrm{M}<0.1)$. The contribution of Chl-a from the pico-phytoplankton assemblage is higher at low Chl-a concentrations and the model parameter $D_{p}$ is representative of the increase in pico-phytoplankton as the total Chl-a concentration tends to zero $\left(D_{p}=0.92\right)$. Above an asymptotic Chl-a concentration of $\sim$ $0.19 \mathrm{mg} \mathrm{m}^{-3}$ for pico-phytoplankton $\left(C_{p}\right)$, additional Chl-a in the system can be attributed to increases in Chl-a within the nano/microphytoplankton assemblage $\left(C_{n, m}\right)$. The model also captures the general trends observed for the phytoplankton size fractions $\left(F_{p}, F_{n, m}\right)$, where the fraction of small (larger) cells decreases (increases) with the total Chl-a concentration.

Although the model of Brewin et al. (2015a) displays the same general trend, it underestimates $C_{p}$ and $F_{p}$, and overestimates $C_{n, m}$ and $F_{n, m}$, for a given total Chl-a concentration (Fig. 3). We note that these differences are apparent regardless of the choice of regression coefficients for Eq. (2) (Supplementary Fig. 2). Prior to the re-tuning of the size model, Brewin et al. (2015a) had set the value of the model 

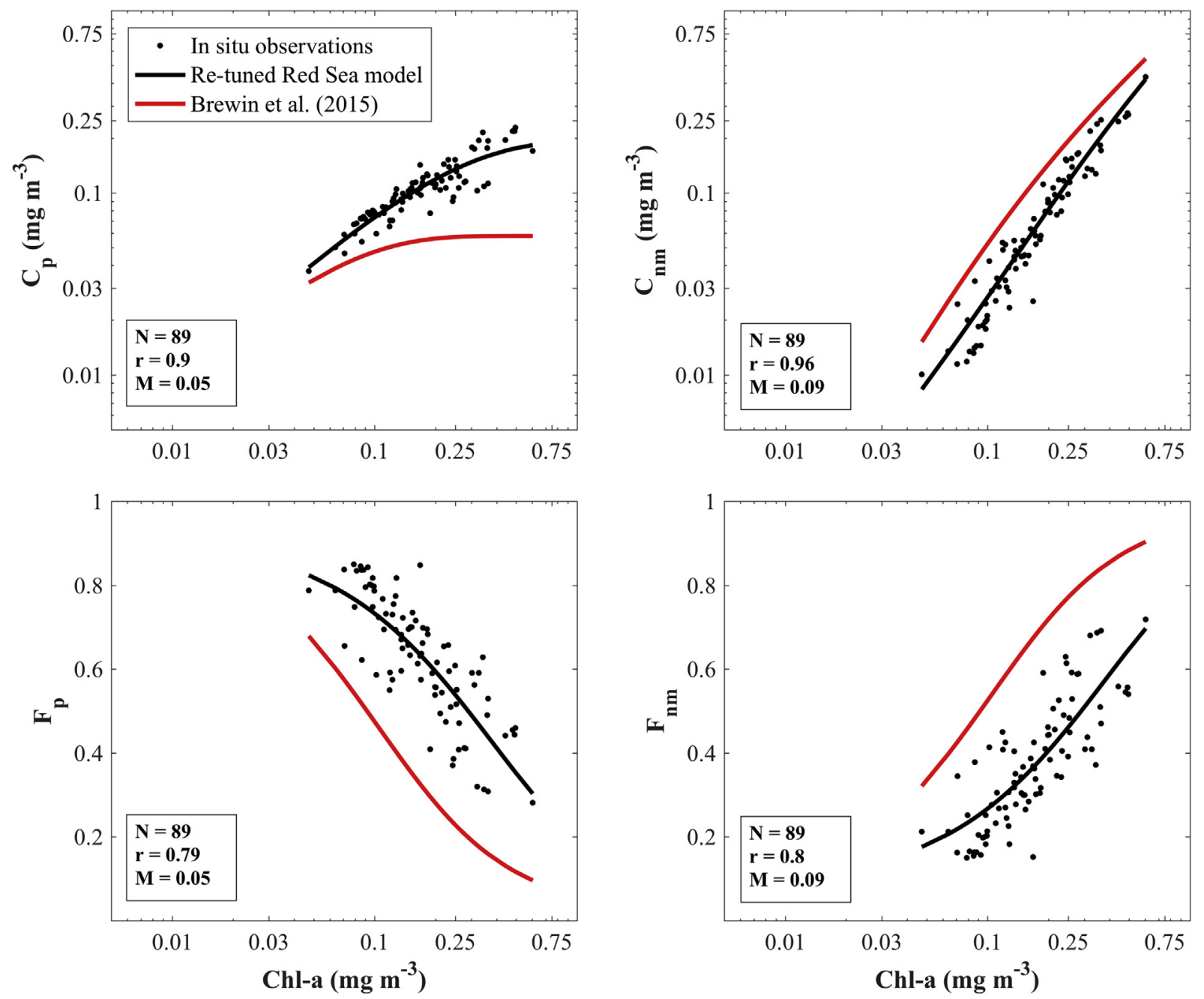

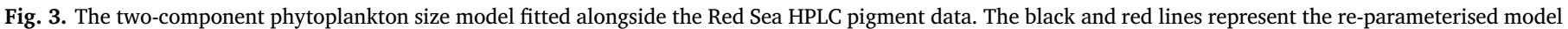

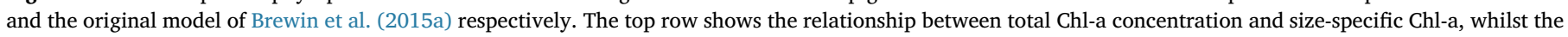

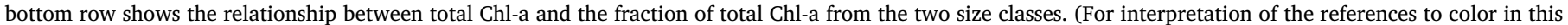
figure legend, the reader is referred to the web version of this article.)

parameter $C_{p}{ }^{m}$ (the maximum Chl-a concentration reached by the picophytoplankton population) at $0.06 \mathrm{mg} \mathrm{m}^{-3}$ (Table 3). Considering the updated model parameter in this study $\left(C_{p}{ }^{m}=0.19 \mathrm{mg} \mathrm{m}^{-3}\right)$, the previous value of $C_{p}{ }^{m}$ utilised by Brewin et al. (2015a), which was derived using HPLC datasets collected in the eastern North Atlantic Ocean (see Brotas et al., 2013), probably under-represents the contribution of the pico-phytoplankton population. Indeed, Brewin et al. (2015a) and Kheireddine et al. (2017) revealed that pico-phytoplankton constituted the dominant size class in the Red Sea, although in the case of the latter study, community structure was found to be fairly heterogeneous due to the mesoscale variability of the region.

\subsection{Satellite validation of size-specific Chl-a concentrations and size fractions}

Satellite-derived observations of Chl-a concentration from the independent matchup dataset were used as input to the re-parameterised two-component size class model, and accordingly, size-specific Chl-a and size fractions were derived. The resultant relationships between the satellite and in situ data are presented in Fig. 4. Generally, satellite estimates of size-specific Chl-a concentration match the in situ observations well. For both $C_{p}$ and $C_{n, m}$, high r values $(r>0.80)$ and low MAD $(\mathrm{M}<0.2)$ are obtained. A slight negative bias occurs for both size classes $(-0.11)$, which is most likely related to the underestimation of total Chl-a from the OC4-RG algorithm (Fig. 2). To further assess the performance of the re-parameterised model, we present the results of statistical tests computed for matchups obtained using the previous model parameters of Brewin et al. (2015a) (Fig. 4). Overall, following model re-parameterisation, the bias is closer to zero, the MAD is smaller and the RMSD is approximately halved (excluding the RMSD associated with the size-specific Chl-a concentration of the combined nano-micro assemblage $\left[\mathrm{C}_{n, m}\right]$ ). In addition, the RMSD of $C_{p}$ presented here $(\psi=0.13)$ is lower than what has been observed in the global ocean (Brewin et al., 2015b), the North Atlantic (Brewin et al., 2017a) the waters off Central-Southern Chile (Corredor-Acosta et al., 2018) and South Africa (Lamont et al., 2018). Satellite-derived size fractions $\left(F_{p}\right.$ and $\left.F_{n, m}\right)$ are also in good agreement with the in situ observations $(r=0.67)$ and the relationships are characterised by low $\operatorname{MAD}(\mathrm{M}=0.09)$ and low biases $(\delta= \pm 0.02)$. We note that as $F_{n, m}=1$ - $F_{p}$ (see Eq. (3)), the statistical parameters computed for the matchups of $F_{p}$ and $F_{n, m}$ are identical (although characterised by a change of sign for the case of $\delta$ ).

To investigate spatial gradients in satellite estimates of phytoplankton size structure, we present an 8-day composite image of the pico- and nano/micro-phytoplankton fractions in the CRS region, as well as total Chl-a concentration (Fig. 5). The composite image represents the period 1st - 9th April 2015, corresponding approximately to the sampling dates of the NC2 cruise conducted in the CRS (3rd - 9th 

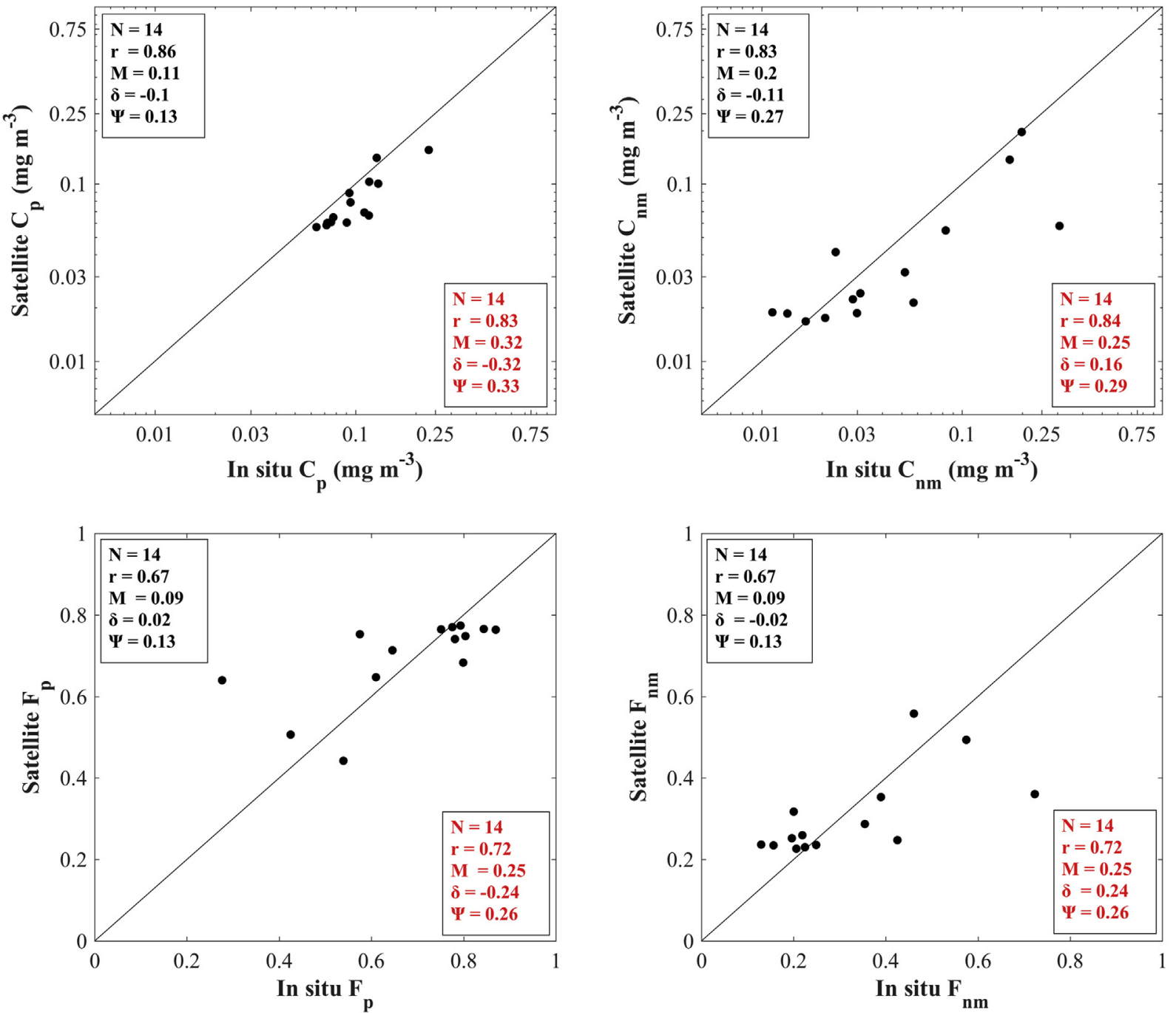

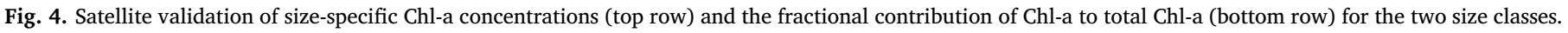

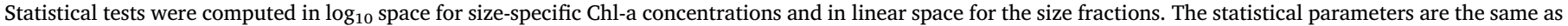

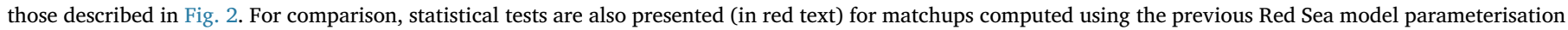
of Brewin et al. (2015a). (For interpretation of the references to color in this figure legend, the reader is referred to the web version of this article.)
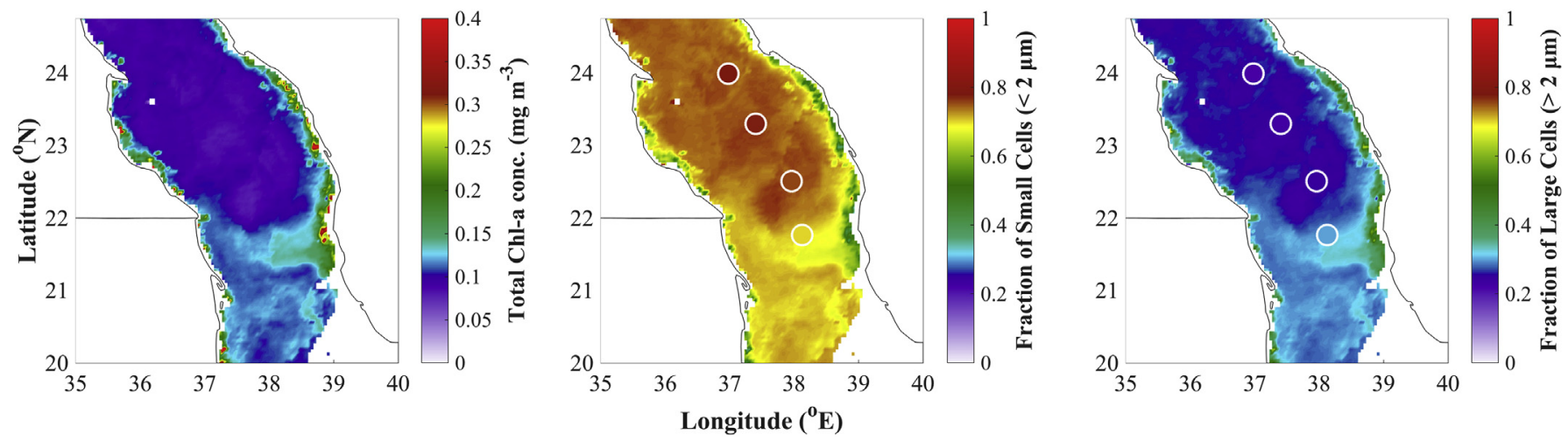

Fig. 5. 8-day climatology (1st - 9th April 2015) of total Chl-a (computed using the OC4-RG algorithm), and the fractional contributions of pico- and the combined

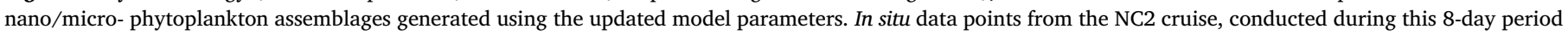

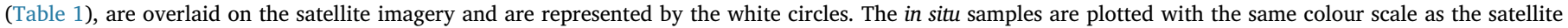
image. 
April 2015, Table 1). For comparison, the in situ size fractions of the pico- and nano/micro- phytoplankton assemblage from the NC2 sampling stations are overlaid on the satellite image (Fig. 5, white circles).

The satellite data effectively capture the spatial variability of in situ size fractions. Lower fractions of nano/micro- phytoplankton $(\sim 20-25 \%$ of the total population) are apparent in the northern region of the CRS $\left(22-24^{\circ} \mathrm{N}\right)$, coinciding with reduced Chl-a concentrations and a higher fraction of pico-phytoplankton (75-80\%). The fraction of nano/micro- phytoplankton increases to $\sim 35 \%$ between 21 and $22^{\circ} \mathrm{N}$, and this is observed by the most southerly in situ sampling station at $\sim 21.75^{\circ} \mathrm{N}$. This region of larger cells is characterised by higher Chl-a concentrations and extends from the eastern coast towards the western coastline. We speculate that this feature may be representative of a mesoscale anticylonic eddy that is a capable of transporting water masses across the basin. Large eddies are known to occur frequently in the CRS $\left(\sim 18-24^{\circ} \mathrm{N}\right)$ (Zhan et al., 2014, 2019) and previous research has demonstrated how these eddies transfer waters rich in Chl-a between the east and west coastlines of the Red Sea (Raitsos et al., 2017). Coral reefs contain elevated concentrations of nutrients from processes such as grazing, sediment re-suspension and bacterial respiration (Acker et al., 2008; Erez, 1990; Rasheed et al., 2002) and instances of higher nutrient availability are known to correlate with larger phytoplankton cells (Marañón, 2015). Indeed, total Chl-a concentration and the fraction of larger cells is notably higher along the coastlines of the CRS, constituting $40-60 \%$ of the total phytoplankton population. The eddy may advect larger cells further offshore between 21 and $22^{\circ} \mathrm{N}$ at its periphery, whilst simultaneously driving a decrease in total Chl-a concentration, and an increase in the contribution of pico-phytoplankton at its core $\left(\sim 22.5^{\circ} \mathrm{N}\right)$, as a result of downwelling and enhanced oligotrophy.

\subsection{Potential caveats}

\subsubsection{In situ estimates of phytoplankton size structure}

We utilised a Red Sea HPLC dataset, in conjunction with a diagnostic pigment approach, to derive in situ measurements of size-specific Chl-a concentration that would be used for the re-parameterisation of the two-component size class model of Brewin et al. (2015a). We note that some diagnostic pigments may be shared by several phytoplankton groups that span a broad range of sizes, and thus may not always be precise biomarkers that enable the definitive differentiation between size classes. In consideration of this, refinements have been made to infer size fractionated Chl-a from the HPLC data using the diagnostic pigment approach. Specifically, we followed the approach of Brewin et al. (2010) to compute in situ values of the pico-phytoplankton size fraction $\left(F_{p}\right)$. This involved apportioning some of the 19'-hexanoyloxyfucoxanthin pigment to pico-phytoplankton at lower Chl-a concentrations, as some pico-eukaryotes contain this pigment. Considering that a two-component model was used to derive pico-phytoplankton and the combined nano/micro-phytoplankton assemblages, it was not necessary to implement further adjustments that have been previously used to account for the partitioning of pigments between micro-phytoplankton and nano-phytoplankton (e.g. Devred et al., 2011). Although we did not compare HPLC-derived estimates of size-fractioned Chl-a with those derived using other methods (e.g. size-fractionated filtration, flow cytometry or molecular analysis), systematic differences in sizefractionated Chl-a between HPLC and other methods have been observed (e.g. Brewin et al., 2014a). Future efforts should focus on collecting concurrent data on size-fractioned Chl-a in the Red Sea using multiple methods, for a more complete and accurate diagnosis of phytoplankton size classes (Nair et al., 2008). Until such datasets become available, the HPLC approach is our only in situ resource, and it has been shown to capture trends in phytoplankton size structure in other oceanic regions (Organelli et al., 2013; Uitz et al., 2008, 2015). Furthermore, the conceptual framework of the two-component model used here has been supported by multiple in situ methods, including: size-fractionated filtration measurements (Brewin et al., 2014b; Gin et al., 2000; Marañón et al., 2012), measurements from flow cytometry and microscopy (Brotas et al., 2013), and measurements of spectral absorption by phytoplankton and particle backscattering (Brewin et al., 2011; Brewin et al., 2012b; Devred et al., 2006, 2011).

\subsubsection{Abundance-based phytoplankton size model}

The abundance-based, three-component model conceptualised by Brewin et al. (2010), and adapted for the Red Sea by Brewin et al. (2015a), has been applied and validated both globally, and for individual oceanic regions (e.g. Brewin et al., 2010, 2012a, 2014a, 2015a, 2015b; Hu et al., 2018; Lamont et al., 2018; Lin et al., 2014). However, abundance-based algorithms infer phytoplankton size structure based on relationships between the total Chl-a concentration and size-fractionated Chl-a, and thus do not directly detect the presence of different phytoplankton size classes. Although these relationships have been shown to hold across the global oceans, deviations from these relationships occur (e.g. Goericke, 2011). Furthermore, for applications of the model to satellite data in optically-complex waters, satellite retrievals of Chl-a may be impacted by the presence of CDOM and nonalgal particles (Hirata et al., 2011; Mouw et al., 2017). Modifications to ecosystem structure as a result of climate change may alter relationships between phytoplankton size structure and total Chl-a (Agirbas et al., 2015; Racault et al., 2014; Sathyendranath et al., 2017). Thus, as well as a need for increased in situ sampling efforts in the Red Sea, recalibration of abundance-based algorithms may be necessary in the future, and may require tying model parameters $\left(C_{p}{ }^{m}\right.$ and $\left.D_{p}\right)$ to other environmental variables amenable from space (see Brewin et al., 2015b, 2017a; Ward, 2015).

Abundance-based algorithms use total Chl-a from satellite remote sensing as input. Thus, the accuracy of satellite Chl-a observations is critical for the derivation of accurate size-fractionated Chl-a data. Perpixel uncertainties in satellite size-fractionated Chl-a data can be derived in two ways: 1 ) by propagating errors in the input total Chl-a through to the output size-fractionated Chl-a, accounting for uncertainties in model parameters (Brewin et al., 2017b); or 2) through comparison of satellite size-fractionated Chl-a with in situ data (validation), by matching the two estimates in time and space (Brewin et al., 2017a). Each approach has its advantages and disadvantages. Model error propagation requires good knowledge of errors in model parameters and model input, and assumes the model is conceptually accurate. Validation generally assumes the in situ data are correct, when in reality the in situ measurements have their own uncertainties that should be considered in the analysis, but are difficult to estimate (Brewin et al., 2014b, 2017a; Nair et al., 2008). In addition, when comparing satellite data with concurrent in situ data, the scales of the observations differ by orders of magnitude (e.g. $1 \mathrm{~L} \mathrm{HPLC}$ sample and $4 \mathrm{~km}$ satellite pixel), which can cause additional uncertainties. In our study we report the uncertainties based on validation (see Fig. 4). It is envisaged that future work could improve on this, perhaps making use of optical water type classification methods (e.g. Brewin et al., 2017a), and by characterising uncertainties in the in situ data, through the collection of concurrent in situ size-fractioned Chl-a data using multiple methods.

\section{Conclusions}

We re-parameterised the two-component phytoplankton size model of Brewin et al. (2015a) using HPLC pigment data collected in the Red Sea. The updated model effectively captures the relationships between in situ measurements of total Chl-a concentration and the Chl-a concentrations of the pico- and combined nano/micro- phytoplankton size classes, and was subsequently applied to remotely-sensed ocean colour observations. Overall, satellite estimates of phytoplankton size structure correlate well with concurrent in situ measurements and also capture the spatial variability in phytoplankton size structure related to 


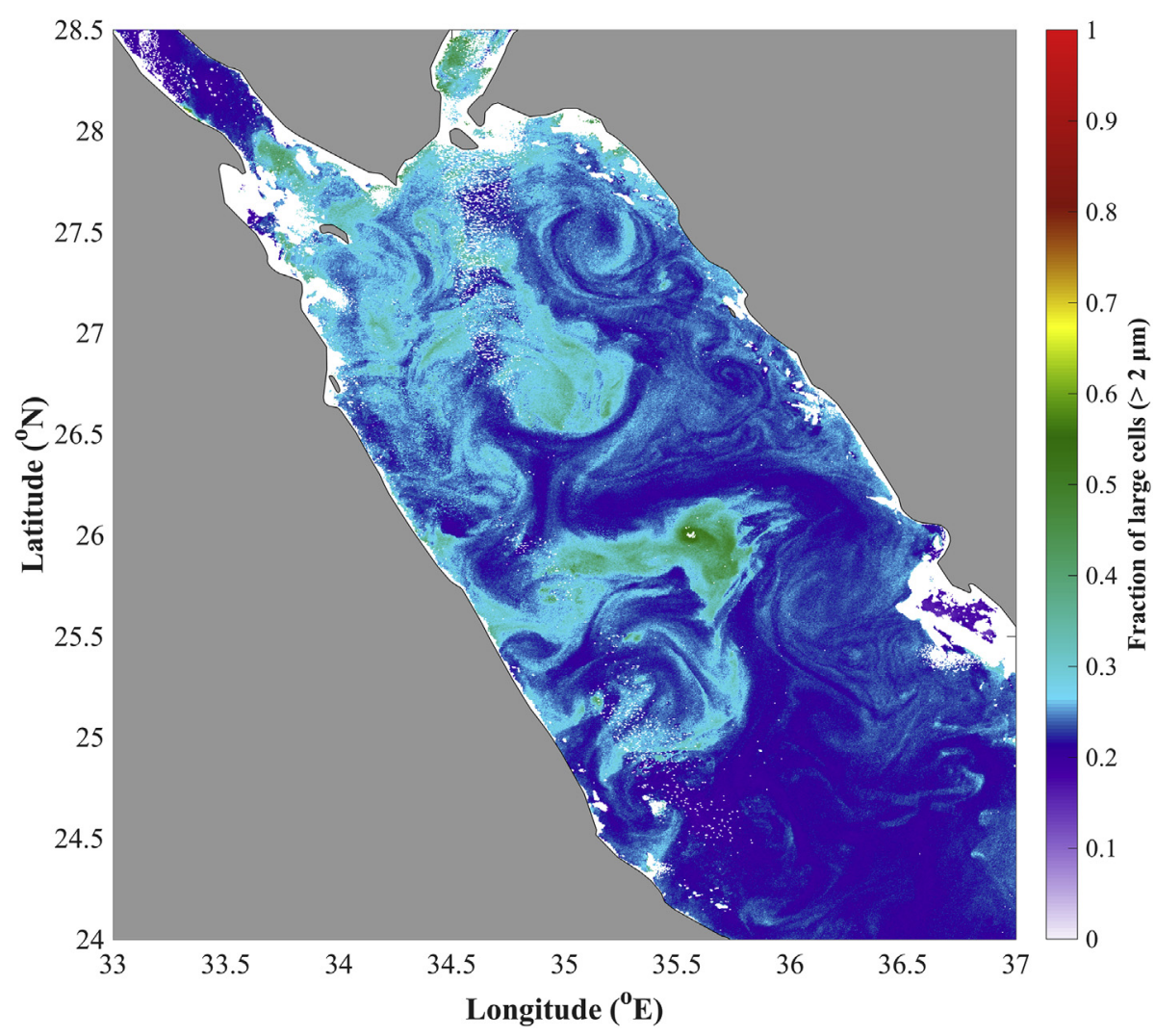

Fig. 6. 8-day climatology (28th February - 7th March 2017) showing the fractional contribution of the combined nano/micro- phytoplankton assemblage at a spatial resolution of $300 \mathrm{~m}$. The size fraction was computed using parameters from the reparameterised model and observations of Chl-a concentration acquired via the Ocean and Land Colour Instrument (OLCI) on-board the SENTINEL-3 satellite (European Space Agency). an anticyclonic eddy.

To our knowledge, this analysis provides the first in situ validation of satellite-derived estimates of phytoplankton size structure in the Red Sea and paves the way for further investigation on the seasonality, interannual variability and phenology of different PSCs. This is likely to be paramount for developing a better understanding of trophic relationships and fisheries dynamics in the region, contributing to the development and implementation of marine ecosystem management schemes. Finally, with the advent of more advanced remote-sensing capabilities, including the launch of next-generation satellite sensors such as OLCI on-board the Sentinel-3a spacecraft (European Space Agency), the large-scale spatiotemporal distribution of ecological indicators, as well as their linkages to mesoscale variability, can be resolved at much finer temporal scales (Fig. 6).

\section{Acknowledgments}

The authors are grateful to the Ocean Colour CCI team (European Space Agency) for providing and processing the Chl-a dataset. The authors also thank Nick Selmes for processing and providing the Sentinel-3 OLCI Chl-a dataset for the Red Sea. The authors express their gratitude to the scientists, officers and crews of the $R / V$ Thuwal, the KAUST Coastal and Marine Resources Core Lab who provided logistical support and assistance during fieldwork, and the Analytical Core Lab for providing facilities for the analyses of the samples collected during the fieldwork. The authors are grateful to Benjamin Kurten, Susana Carvalho, Sarma Yellepeddi, and Joanne Ellis for facilitating the sampling of optical and pigment samples for the research cruises listed. The authors also thank George Krokos for his useful discussions. This work was funded by the KAUST Office of Sponsored Research (OSR) under the Collaborative Research Grant (CRG) program (Grant \# URF/1/ 2979-01-01) and the Virtual Red Sea Initiative (Grant \# REP/1/326801-01). Fieldwork was supported by KAUST baseline funding (BAS/1/ 1032-01-01) attributed to Burton Jones.

\section{Author contributions}

J.A.G., R.J.W.B., D.R.E. \& I.H. designed the research. J.A.G., R.J.W.B. \& D.R.E. carried out the data analysis. J.A.G. wrote the paper. J.A.G., R.J.W.B., \& D.R.E. produced the figures. J.A.G., R.J.W.B., D.R.E., M.K., M.O., B.H.J. \& I.H. contributed to the interpretation of results, the discussion and subsequent edits of the paper.

\section{Appendix A. Supplementary data}

Supplementary data to this article can be found online at https:// doi.org/10.1016/j.rse.2019.111387.

\section{References}

Acker, J., Leptoukh, G., Shen, S., Zhu, T., Kempler, S., 2008. Remotely-sensed chlorophyll a observations of the northern Red Sea indicate seasonal variability and influence of coastal reefs. J. Mar. Syst. 69, 191-204. https://doi.org/10.1016/j.jmarsys.2005.12. 006.

Agirbas, E., Martinez-Vicente, V., Brewin, R.J., Racault, M.F., Airs, R.L., Llewellyn, C.A., 2015. Temporal changes in total and size-fractioned chlorophyll-a in surface waters of three provinces in the Atlantic Ocean (September to November) between 2003 and 2010. J. Mar. Syst. 150, 56-65. https://doi.org/10.1016/j.jmarsys.2015.05.008.

Al-Najjar, T., Badran, M.I., Richter, C., Meyerhoefer, M., Sommer, U., 2007. Seasonal dynamics of phytoplankton in the Gulf of Aqaba, Red Sea. Hydrobiologia 579 (1), 69-83. https://doi.org/10.1007/s10750-006-0365-z.

Bailey, S.W., Werdell, P.J., 2006. A multi-sensor approach for the on-orbit validation of ocean color satellite data products. Remote Sens. Environ. 102, 12-23. https://doi. org/10.1016/J.RSE.2006.01.015.

Berumen, M.L., Hoey, A.S., Bass, W.H., Bouwmeester, J., Catania, D., Cochran, J.E.M., Khalil, M.T., Miyake, S., Mughal, M.R., Spaet, J.L.Y., Saenz-Agudelo, P., 2013. The status of coral reef ecology research in the Red Sea. Coral Reefs 32 (3), 737-748. https://doi.org/10.1007/s00338-013-1055-8.

Boyd, P.W., Newton, P., 1999. Does planktonic community structure determine downward particulate organic carbon flux in different oceanic provinces? Deep-Sea Res. I Oceanogr. Res. Pap. 46, 63-91. https://doi.org/10.1016/S0967-0637(98)00066-1.

Bracher, A., Bouman, H.A., Brewin, R.J., Bricaud, A., Brotas, V., Ciotti, A.M., Clementson, L., Devred, E., Di Cicco, A., Dutkiewicz, S., Hardman-Mountford, N.J., 2017.

Obtaining phytoplankton diversity from ocean color: a scientific roadmap for future development. Front. Mar. Sci. 4, 55. https://doi.org/10.3389/fmars.2017.00055.

Brewin, R.J.W., Sathyendranath, S., Hirata, T., Lavender, S.J., Barciela, R.M., Hardman- 
Mountford, N.J., 2010. A three-component model of phytoplankton size class for the Atlantic Ocean. Ecol. Model. 221, 1472-1483. https://doi.org/10.1016/j.ecolmodel. 2010.02.014.

Brewin, R.J.W., Devred, E., Sathyendranath, S., Lavender, S.J., Hardman-Mountford, N.J., 2011. Model of phytoplankton absorption based on three size classes. Appl. Opt. 50, 4535. https://doi.org/10.1364/AO.50.004535.

Brewin, R.J.W., Hirata, T., Hardman-Mountford, N.J., Lavender, S.J., Sathyendranath, S., Barlow, R., 2012a. The influence of the Indian Ocean Dipole on interannual variations in phytoplankton size structure as revealed by Earth observation. Deep. Res. Part II Top. Stud. Oceanogr. 77-80, 117-127. https://doi.org/10.1016/j.dsr2.2012. 04.009.

Brewin, R.J.W., Dall'Olmo, G., Sathyendranath, S., Hardman-Mountford, N.J., 2012b. Particle backscattering as a function of chlorophyll and phytoplankton size structure in the open-ocean. Opt. Express 20, 17632. https://doi.org/10.1364/OE.20.017632.

Brewin, R.J.W., Raitsos, D.E., Pradhan, Y., Hoteit, I., 2013. Comparison of chlorophyll in the Red Sea derived from MODIS-aqua and in vivo fluorescence. Remote Sens. Environ. 136, 218-224. https://doi.org/10.1016/J.RSE.2013.04.018.

Brewin, R.J.W., Sathyendranath, S., Lange, P.K., Tilstone, G., 2014a. Comparison of two methods to derive the size-structure of natural populations of phytoplankton. Deep Sea Res. Part I Oceanogr. Res. Pap. 85, 72-79. https://doi.org/10.1016/J.DSR.2013. 11.007.

Brewin, R.J.W., Sathyendranath, S., Tilstone, G., Lange, P.K., Platt, T., 2014b. A multicomponent model of phytoplankton size structure. J. Geophys. Res. Ocean. 119, 3478-3496. https://doi.org/10.1002/2014JC009859.

Brewin, R.J.W., Raitsos, D.E., Dall'Olmo, G., Zarokanellos, N., Jackson, T., Racault, M.F., Boss, E.S., Sathyendranath, S., Jones, B.H., Hoteit, I., 2015a. Regional ocean-colour chlorophyll algorithms for the Red Sea. Remote Sens. Environ. 165, 64-85. https:// doi.org/10.1016/j.rse.2015.04.024.

Brewin, R.J.W., Sathyendranath, S., Jackson, T., Barlow, R., Brotas, V., Airs, R., Lamont, T., 2015b. Influence of light in the mixed-layer on the parameters of a three-component model of phytoplankton size class. Remote Sens. Environ. 168, 437-450. https://doi.org/10.1016/j.rse.2015.07.004.

Brewin, R.J.W., Sathyendranath, S., Müller, D., Brockmann, C., Deschamps, P.-Y., Devred, E., Doerffer, R., Fomferra, N., Franz, B., Grant, M., Groom, S., Horseman, A., Hu, C., Krasemann, H., Lee, Z., Maritorena, S., Mélin, F., Peters, M., Platt, T., Regner, P., Smyth, T., Steinmetz, F., Swinton, J., Werdell, J., White, G.N., 2015c. The ocean colour climate change initiative: III. A round-robin comparison on in-water bio-optical algorithms. Remote Sens. Environ. 162, 271-294. https://doi.org/10.1016/J. RSE.2013.09.016.

Brewin, R.J.W., Dall'Olmo, G., Pardo, S., van Dongen-Vogels, V., Boss, E.S., 2016. Underway spectrophotometry along the Atlantic meridional transect reveals high performance in satellite chlorophyll retrievals. Remote Sens. Environ. 183, 82-97. https://doi.org/10.1016/j.rse.2016.05.005.

Brewin, R.J.W., Ciavatta, S., Sathyendranath, S., Jackson, T., Tilstone, G., Curran, K., Airs, R.L., Cummings, D., Brotas, V., Organelli, E., Dall'Olmo, G., Raitsos, D.E., 2017a Uncertainty in ocean-color estimates of chlorophyll for phytoplankton groups. Front. Mar. Sci. 4, 104. https://doi.org/10.3389/fmars.2017.00104.

Brewin, R.J.W., Jackson, T., Cain, T., Miller, P.I., Lange, P.K., Misra, A., Airs, R.L., 2017b. Modelling size-fractionated primary production in the Atlantic Ocean from remote sensing. Prog. Oceanogr. 158, 130-149. https://doi.org/10.1016/J.POCEAN.2017. 02.002 .

Bricaud, A., Babin, M., Claustre, H., Ras, J., Tièche, F., 2010. Light absorption properties and absorption budget of Southeast Pacific waters. J. Geophys. Res. 115, C08009. https://doi.org/10.1029/2009JC005517.

Briggs, N., Perry, M.J.P., Cetinic', I., Lee, C., D’Asaro, E., Gray, A.M., Rehm, E., 2011. High-resolution observations of aggregate flux during a sub-polar North Atlantic spring bloom. Deep-Sea Res. I Oceanogr. Res. Pap. 58, 1031-1039. https://doi.org/ 10.1016/j.dsr.2011.07.007.

Brito, A.C., Sá, C., Brotas, V., Brewin, R.J., Silva, T., Vitorino, J., Platt, T., Sathyendranath, S., 2015. Effect of phytoplankton size classes on bio-optical properties of phytoplankton in the Western Iberian coast: application of models. Remote Sens. Environ. 156, 537-550. https://doi.org/10.1016/j.rse.2014.10.020.

Brotas, V., Brewin, R.J.W., Sá, C., Brito, A.C., Silva, A., Mendes, C.R., Diniz, T., Kaufmann, M., Tarran, G., Groom, S.B., Platt, T., Sathyendranath, S., 2013. Deriving phytoplankton size classes from satellite data: validation along a trophic gradient in the eastern Atlantic Ocean. Remote Sens. Environ. 134, 66-77. https://doi.org/10.1016/ J.RSE. 2013.02.013.

Campbell, J.W., 1995. The lognormal distribution as a model for bio-optical variability in the sea. J. Geophys. Res. 100, 13237. https://doi.org/10.1029/95JC00458.

Cantin, N.E., Cohen, A.L., Karnauskas, K.B., Tarrant, A.M., McCorkle, D.C., 2010. Ocean warming slows coral growth in the central red sea. Science 329 (5989), 322-325. https://doi.org/10.1126/science.1190182.

Carvalho, S., Kurten, B., Krokos, G., Hoteit, I., 2018. The Red Sea. In: Sheppard, C. (Ed.), Introduction to World Seas: An Environmental Evaluation, 2nd edition. The Indian Ocean to the Pacific Volume II Academic Press.

Chaidez, V., Dreano, D., Agusti, S., Duarte, C.M., Hoteit, I., 2017. Decadal trends in Red Sea maximum surface temperature. Sci. Rep. 1-8. https://doi.org/10.1038/s41598017-08146-z.

Chisholm, S.W., 1992. Phytoplankton Size. In Primary Productivity and Biogeochemical Cycles in the Sea. Springer, Boston, MA.

Claustre, H., 1994. The trophic status of various oceanic provinces as revealed by phytoplankton pigment signatures. Limnol. Oceanogr. 39 (5), 1206-1210. https://doi. org/10.4319/lo.1994.39.5.1206.

Corredor-Acosta, A., Morales, C.E., Brewin, R.J.W., Auger, P.A., Pizarro, O., Hormazabal, S., Anabalón, V., 2018. Phytoplankton size structure in association with mesoscale eddies off central-southern Chile: the satellite application of a phytoplankton size- class model. Remote Sens. 10. https://doi.org/10.3390/rs10060834.

Devred, E., Sathyendranath, S., Stuart, V., Maass, H., Ulloa, O., Platt, T., 2006. A TwoComponent Model of Phytoplankton Absorption in the Open Ocean: Theory and Applications. 111. pp. 1-11. https://doi.org/10.1029/2005JC002880.

Devred, E., Sathyendranath, S., Stuart, V., Platt, T., 2011. A three component classification of phytoplankton absorption spectra: application to ocean-color data. Remote Sens. Environ. 115 (9), 2255-2266. https://doi.org/10.1016/j.rse.2011.04.025.

Doney, S.C., Lima, I., Moore, J.K., Lindsay, K., Behrenfeld, M.J., Westberry, T.K., Mahowald, N., Glover, D.M., Takahashi, T., 2009. Skill metrics for confronting global upper ocean ecosystem-biogeochemistry models against field and remote sensing data. J. Mar. Syst. 76 (1-2), 95-112. https://doi.org/10.1016/j.jmarsys.2008.05.015.

Dreano, D., Raitsos, D.E., Gittings, J., Krokos, G., Hoteit, I., 2016. The Gulf of Aden intermediate water intrusion regulates the southern Red Sea summer phytoplankton blooms. PLoS One 1 (20). https://doi.org/10.1371/journal.pone.0168440.

Efron, B., 1979. Bootstrap methods: another look at the jackknife. Ann. Stat. 7, 1-26.

Eppley, R.W., Peterson, B.J., 1979. Particulate organic matter flux and planktonic new production in the deep ocean. Nature 282, 677-680. https://doi.org/10.1038/ $282677 \mathrm{a} 0$.

Erez, J., 1990. On the importance of food sources in coral-reef ecosystems. Ecosystems of the world 25, 411-418.

Friedrichs, M.A.M., Carr, M.-E., Barber, R.T., Scardi, M., Antoine, D., Armstrong, R.A., Asanuma, I., Behrenfeld, M.J., Buitenhuis, E.T., Chai, F., Christian, J.R., Ciotti, A.M., Doney, S.C., Dowell, M., Dunne, J., Gentili, B., Gregg, W., Hoepffner, N., Ishizaka, J., Kameda, T., Lima, I., Marra, J., Mélin, F., Moore, J.K., Morel, A., O'Malley, R.T., O'Reilly, J., Saba, V.S., Schmeltz, M., Smyth, T.J., Tjiputra, J., Waters, K., Westberry, T.K., Winguth, A., 2009. Assessing the uncertainties of model estimates of primary productivity in the tropical Pacific Ocean. J. Mar. Syst. 76, 113-133. https://doi.org/ 10.1016/J.JMARSYS.2008.05.010.

Gin, K.Y.-H., Lin, X., Zhang, S., 2000. Dynamics and size structure of phytoplankton in the coastal waters of Singapore. J. Plankton Res. 22, 1465-1484. https://doi.org/10. 1093/plankt/22.8.1465.

Gittings, J.A., Raitsos, D.E., Racault, M., Brewin, R.J.W., Pradhan, Y., Sathyendranath, S., Platt, T., 2017. Remote sensing of environment seasonal phytoplankton blooms in the Gulf of Aden revealed by remote sensing. Remote Sens. Environ. 189, 56-66. https:// doi.org/10.1016/j.rse.2016.10.043.

Gittings, J.A., Raitsos, D.E., Krokos, G., Hoteit, I., 2018. Impacts of warming on phytoplankton abundance and phenology in a typical tropical marine ecosystem. Sci. Rep. 8, 2240. https://doi.org/10.1038/s41598-018-20560-5.

Gittings, J.A., Raitsos, D.E., Kheireddine, M., Racault, M.-F., Claustre, H., Hoteit, I., 2019. Evaluating tropical phytoplankton phenology metrics using contemporary tools. Sci. Rep. 9, 674. https://doi.org/10.1038/s41598-018-37370-4.

Gladstone, W., Curley, B., Shokri, M.R., 2013. Environmental impacts of tourism in the Gulf and the Red Sea. Mar. Pollut. Bull. 72 (2), 375-388. https://doi.org/10.1016/j. marpolbul.2012.09.017.

GoeRicke, R., 2011. The size structure of marine phytoplankton-what are the rules. CalCOFI Rep 52, 198-204.

Gohin, F., Druon, J.N., Lampert, L., 2002. A five channel chlorophyll concentration algorithm applied to SeaWiFS data processed by SeaDAS in coastal waters. Int. J. Remote Sens. 23, 1639-1661. https://doi.org/10.1080/01431160110071879.

Guidi, L., Stemmann, L., Jackson, G.A., Ibanez, F., Claustre, H., Legendre, L., Picheral, M., Gorskya, G., 2009. Effects of phytoplankton community on production, size, and export of large aggregates: a world-ocean analysis. Limnol. Oceanogr. 54, 1951-1963. https://doi.org/10.4319/10.2009.54.6.1951.

Hirata, T., Hardman-Mountford, N.J., Brewin, R.J.W., Aiken, J., Barlow, R., Suzuki, K., Isada, T., Howell, E., Hashioka, T., Noguchi-Aita, M., Yamanaka, Y., 2011. Synoptic relationships between surface chlorophyll-a and diagnostic pigments specific to phytoplankton functional types. Biogeosciences 8, 311-327. https://doi.org/10. 5194/bg-8-311-2011.

Hu, C., Lee, Z., Franz, B., 2012. Chlorophyll a algorithms for oligotrophic oceans: a novel approach based on three-band reflectance difference. J. Geophys. Res. Ocean. 117. https://doi.org/10.1029/2011JC007395.

$\mathrm{Hu}$, et al., 2018. Comparison of satellite-derived phytoplankton size classes using in-situ measurements in the South China Sea. Remote Sens. 10. https://doi.org/10.3390/ rs10040526.

Ismael, A.A., 2015. Phytoplankton of the Red Sea. Springer, Berlin, Heidelberg, pp. 567-583. https://doi.org/10.1007/978-3-662-45201-1_32.

Kheireddine, M., Ouhssain, M., Claustre, H., Uitz, J., Gentili, B., Jones, B.H., 2017. Assessing pigment-based phytoplankton community distributions in the Red Sea Front. Mar. Sci. 4, 132. https://doi.org/10.3389/fmars.2017.00132.

Kheireddine, M., Ouhssain, M., Organelli, E., Bricaud, A., Jones, B.H., 2018a. Light absorption by suspended particles in the Red Sea: effect of phytoplankton community size structure and pigment composition. Journal of Geophysical Research: Oceans 123 (2), 902-921.

Kheireddine, M., Ouhssain, M., Calleja, M.L., Morán, X.A.G., Sarma, Y.V.B., Tiwari, S.P., Jones, B.H., 2018b. Characterization of light absorption by chromophoric dissolved organic matter (CDOM) in the upper layer of the Red Sea. Deep Sea Res. Part I Oceanogr. Res. Pap. 133, 72-84. https://doi.org/10.1016/J.DSR.2018.02.001.

Kostadinov, T.S., Siegel, D.A., Maritorena, S., 2009. Retrieval of the particle size distribution from satellite ocean color observations. J. Geophys. Res. Ocean. 114, 1-22. https://doi.org/10.1029/2009JC005303.

Krokos, G., Papardopoulos, V.P., Sofianos, S.S., Ombao, H., Dybczak, P., Hoteit, I., 2019. Natural climate oscillations may counteract Red Sea warming over the coming decades. Geophys. Res. Lett. 46, 3454-3461. https://doi.org/10.1029/2018GL081397.

Lamont, T., Barlow, R.G., Brewin, R.J.W., 2018. Variations in remotely-sensed phytoplankton size structure of a cyclonic eddy in the Southwest Indian Ocean. Remote Sens. 10. https://doi.org/10.3390/rs10071143. 
Laws, E.A., Falkowski, P.G., Smith Jr., W.O., Ducklow, H., McCarth, J.J., 2000. Temperature effects on export production in the open ocean. Glob. Biogeochem. Cycles 14, 1231-1246. https://doi.org/10.1029/1999GB001229.

Legendre, L., Le Fevre, J., 1991. From individual plankton cells to pelagic marine ecosystems and to global biogeochemical cycles. In: Particle Analysis in Oceanography. Springer, Berlin, Heidelberg.

Lin, J., Cao, W., Wang, G., Hu, S., 2014. Satellite-observed variability of phytoplankton size classes associated with a cold eddy in the South China Sea. Mar. Pollut. Bull. 83, 190-197. https://doi.org/10.1016/j.marpolbul.2014.03.052.

Liu, X., Devred, E., Johnson, C., 2018. Remote sensing of phytoplankton size class in Northwest Atlantic from 1998 to 2016: bio-optical algorithms comparison and application. Remote Sens. 10 (7), 1028. https://doi.org/10.3390/rs10071028.

Marañón, E., 2015. Cell size as a key determinant of phytoplankton metabolism and community structure. Annu. Rev. Mar. Sci. 7, 241-264. https://doi.org/10.1146/ annurev-marine-010814-015955.

Marañón, E., Cermeño, P., Latasa, M., Tadonléké, R.D., 2012. Temperature, resources, and phytoplankton size structure in the ocean. Limnol. Oceanogr. 57, 1266-1278. https://doi.org/10.4319/lo.2012.57.5.1266.

McCave, I., 1975. Vertical flux of particles in the ocean. Deep Sea Res. Oceanogr. Abstr. 22 (7), 491-502.

Moloney, C.L., Field, J.G., 1991. The size-based dynamics of plankton food webs. I. a simulation model of carbon and nitrogen flows. J. Plankton Res. 13 (5), 1003-1038.

Monroe, A.A., Ziegler, M., Roik, A., Röthig, T., Hardenstine, R.S., Emms, M.A., Jensen, T., Voolstra, C.R., Berumen, M.L., 2018. In situ observations of coral bleaching in the central Saudi Arabian Red Sea during the 2015/2016 global coral bleaching event. PLoS One 13 (4), e0195814. https://doi.org/10.1371/journal.pone.0195814.

Morel, A., Gentili, B., 2009. The dissolved yellow substance and the shades of blue in the Mediterranean Sea. Biogeosciences 6, 2625-2636. https://doi.org/10.5194/bg-62625-2009.

Moses, W.J., Gitelson, A.A., Berdnikov, S., Saprygin, V., Povazhnyi, V., 2012. Operational MERIS-based NIR-red algorithms for estimating chlorophyll-a concentrations in coastal waters - the Azov Sea case study. Remote Sens. Environ. 121, 118-124. https://doi.org/10.1016/j.rse.2012.01.024.

Mouw, C.B., Hardman-Mountford, N.J., Alvain, S., Bracher, A., Brewin, R.J.W., Bricaud, A., Ciotti, A.M., Devred, E., Fujiwara, A., Hirata, T., Hirawake, T., Kostadinov, T.S., Roy, S., Uitz, J., 2017. A consumer's guide to satellite remote sensing of multiple phytoplankton groups in the global ocean. Front. Mar. Sci. 4. https://doi.org/10. 3389/fmars.2017.00041.

Nair, A., Platt, T., Morales, J., Stuart, V., Forget, M.-H., Devred, E., Bouman, H., 2008. Remote sensing of phytoplankton functional types. Remote Sens. Environ. 112, 3366-3375. https://doi.org/10.1016/J.RSE.2008.01.021.

Nassar, M.Z., Mohamed, H.R., Khiray, H.M., Rashedy, S.H., 2014. Seasonal fluctuations of phytoplankton community and physico-chemical parameters of the north western part of the Red Sea, Egypt. Egypt. J. Aquat. Res. 40 (4), 395-403. https://doi.org/10. 1016/j.ejar.2014.11.002.

Niemi, G.J., McDonald, M.E., 2004. Application of ecological indicators. Annu. Rev. Ecol. Evol. Syst. 35, 89-111.

O'Reilly, J.E., Werdell, P.J., 2019. Chlorophyll algorithms for ocean color sensors - OC4, OC5 \& OC6. Remote Sens. Environ. 229, 32-47. https://doi.org/10.1016/J.RSE. 2019.04.021.

O’Reilly, J.E., Maritorena, S., Siegel, D., O'Brien, M.O., Toole, D., Mitchell, B.G., Kahru, M., Chavez, F., Strutton, P.G., Cota, G.F., Hooker, S.B., McClain, C., Carder, K., Muller-Karger, F., Harding, L., Magnuson, A., Phinney, D., Moore, G., Aiken, J., Arrigo, K.R., Letelier, R.M., Culver, M., 2000. Ocean color chlorophyll a algorithms for SeaWiFS, OC2, and OC4: Version 4. In: McClain, C.R. (Ed.), SeaWiFS Postlaunch Calibration and Validation Analyses. 11. Goddard Space Flight Center, Greenbelt, Md, pp. 9-23.

Organelli, E., Bricaud, A., Antoine, D., Uitz, J., 2013. Multivariate approach for the retrieval of phytoplankton size structure from measured light absorption spectra in the Mediterranean Sea (BOUSSOLE site). Appl. Opt. 52, 2257. https://doi.org/10.1364/ A0.52.002257.

Organelli, E., Bricaud, A., Antoine, D., Matsuoka, A., 2014. Seasonal dynamics of light absorption by chromophoric dissolved organic matter (CDOM) in the NW Mediterranean Sea (BOUSSOLE site). Deep Sea Res. Part I Oceanogr. Res. Pap. 91, 72-85. https://doi.org/10.1016/J.DSR.2014.05.003.

Osman, E.O., Smith, D.J., Ziegler, M., Kürten, B., Conrad, C., El-Haddad, K.M., Voolstra, C.R., Suggett, D.J., 2018. Thermal refugia against coral bleaching throughout the northern Red Sea. Glob. Change Biol. 24 (2), 474-484. https://doi.org/10.1111/gcb. 13895.

Papadopoulos, V.P., Zhan, P., Sofianos, S.S., Raitsos, D.E., Qurban, M., Abualnaja, Y., Bower, A., Kontoyiannis, H., Pavlidou, A., Asharaf, T.T.M., Zarokanellos, N., Hoteit, I., 2015. Factors governing the deep ventilation of the Red Sea. J. Geophys. Res. Ocean. 120, 7493-7505. https://doi.org/10.1002/2015JC010996.

Parsons, T.R., Lalli, C.M., 2002. Jellyfish population explosions: revisiting a hypothesis of possible causes. La mer 40 (3), 111-121.

Pearman, J.K., Kürten, S., Sarma, Y.V.B., Jones, B.H., Carvalho, S., 2016. Biodiversity patterns of plankton assemblages at the extremes of the Red Sea. FEMS Microbiol. Ecol. 92, 1-13. https://doi.org/10.1093/femsec/fiw002.

Platt, T., Sathyendranath, S., 2008. Ecological indicators for the pelagic zone of the ocean from remote sensing. Remote Sens. Environ. 112 (8), 3426-3436. https://doi.org/10. 1016/j.rse.2007.10.016.

Platt, T., White III, G.N., Zhai, L., Sathyendranath, S., Roy, S., 2009. The phenology of phytoplankton blooms: ecosystem indicators from remote sensing. Ecol. Model. 220 (21), 3057-3069. https://doi.org/10.1016/j.ecolmodel.2008.11.022.

Qurban, M.A.B., Wafar, M., Heinle, M., 2019. Phytoplankton and Primary Production in the Red Sea. Springer, Cham, pp. 491-506. https://doi.org/10.1007/978-3-319-
99417-8_27.

Racault, M.F., Platt, T., Sathyendranath, S., Ağirbaş, E., Martinez Vicente, V., Brewin, R., 2014a. Plankton indicators and ocean observing systems: support to the marine ecosystem state assessment. J. Plankton Res. 36 (3), 621-629. https://doi.org/10. 1093/plankt/fbu016.

Racault, M.F., Raitsos, D.E., Berumen, M.L., Brewin, R.J.W., Platt, T., Sathyendranath, S., Hoteit, I., 2015. Phytoplankton phenology indices in coral reef ecosystems: application to ocean-color observations in the Red Sea. Remote Sens. Environ. 160, 222-234. https://doi.org/10.1016/j.rse.2015.01.019.

Raimbault, P., 1988. Size fractionation of phytoplankton in the Ligurian Sea and the Algerian Basin (Mediterranean Sea): size distribution versus total concentration. Mar. Microb. Food Webs 3, 1-7.

Raitsos, D.E., Hoteit, I., Prihartato, P.K., Chronis, T., Triantafyllou, G., Abualnaja, Y. 2011. Abrupt warming of the Red Sea. Geophys. Res. Lett. 38, 1-5. https://doi.org/ 10.1029/2011GL047984.

Raitsos, D.E., Pradhan, Y., Brewin, R.J.W., Stenchikov, G., Hoteit, I., 2013. Remote sensing the phytoplankton seasonal succession of the Red Sea. PLoS One 8. https://doi. org/10.1371/journal.pone.0064909.

Raitsos, D.E., Yi, X., Platt, T., Racault, M.F., Brewin, R.J.W., Pradhan, Y., Papadopoulos, V.P., Sathyendranath, S., Hoteit, I., 2015. Monsoon oscillations regulate fertility of the Red Sea. Geophys. Res. Lett. 42, 855-862. https://doi.org/10.1002/ 2014GL062882.

Raitsos, D.E., Brewin, R.J.W., Zhan, P., Dreano, D., Pradhan, Y., Nanninga, G.B., Hoteit, I., 2017. Sensing coral reef connectivity pathways from space. Sci. Rep. 7, 9338. https:// doi.org/10.1038/s41598-017-08729-w.

Ras, J., Claustre, H., Uitz, J., 2008. Spatial variability of phytoplankton pigment distributions in the subtropical South Pacific Ocean: comparison between in situ and predicted data. Biogeosciences 5 (2), 353-369. https://doi.org/10.5194/bg-5-3532008.

Rasheed, M., Badran, M.I., Richter, C., Huettel, M., 2002. Effect of reef framework and bottom sediment on nutrient enrichment in a coral reef of the Gulf of Aqaba, Red Sea. Mar. Ecol. Prog. Ser. https://doi.org/10.2307/24866066.

Sammartino, M., Di Cicco, A., Marullo, S., Santoleri, R., 2015. Spatio-temporal variability of micro-, nano- and pico-phytoplankton in the Mediterranean Sea from satellite ocean colour data of SeaWiFS. Ocean Sci. 11, 759-778. https://doi.org/10.5194/os11-759-2015.

Sathyendranath, S., Platt, T., 2007. Spectral effects in bio-optical control on the ocean system. Oceanologia 49 (1), 5-39.

Sathyendranath, S., Cota, G., Stuart, V., Maass, H., Platt, T., 2001. Remote sensing of phytoplankton pigments: a comparison of empirical and theoretical approaches. Int. J. Remote Sens. 22, 249-273. https://doi.org/10.1080/014311601449925.

Sathyendranath, S., Brewin, B., Mueller, D., Doerffer, R., Krasemann, H., Melin, F., Brockmann, C., Fomferra, N., Peters, M., Grant, M., Steinmetz, F., Deschamps, P.-Y., Swinton, J., Smyth, T., Werdell, J., Franz, B., Maritorena, S., Devred, E., Lee, Z., Hu, C., Regner, P., 2012. Ocean colour climate change initiative - approach and initial results. In: 2012 IEEE International Geoscience and Remote Sensing Symposium. IEEE, pp. 2024-2027. https://doi.org/10.1109/IGARSS.2012.6350979.

Sathyendranath, S., Aiken, J., Alvain, S., Barlow, R., Bouman, H., Bracher, A., Brewin, R., Bricaud, A., Brown, C.W., Ciotti, A.M., Clementson, L.A., Craig, S.E., Devred, E., Hardman-Mountford, N., Hirata, T., Hu, C., Kostadinov, T.S., Lavender, S., Loisel, H., Moore, T.S., Morales, J., Mouw, C.B., Nair, A., Raitsos, D., Roesler, C., Shutler, J.D., Sosik, H.M., Soto, I., Stuart, V., Subramaniam, A., Uitz, J., 2014. Phytoplankton functional types from space. In: Sathyendranath, S., Stuart, V. (Eds.), Reports of the International Ocean-Colour Coordinating Group (IOCCG); 15. International OceanColour Coordinating Group, Dartmouth, Nova Scotia, B2Y 4A2, Canada (156 p., ISBN: ISSN 1098-6030).

Sathyendranath, S., Brewin, R.J.W., Brockmann, C., Brotas, V., Ciavatta, S., Chuprin, A., Couto, A.B., Doerffer, R., Dowell, M., Grant, M., 2016. Creating an ocean-colour time series for use in climate studies: the experience of the ocean-colour climate change initiative. Remote Sens. Env.

Sathyendranath, S., Brewin, R.J.W., Jackson, T., Mélin, F., Platt, T., 2017. Ocean-colour products for climate-change studies: what are their ideal characteristics? Remote Sens. Environ. 203, 125-138. https://doi.org/10.1016/J.RSE.2017.04.017.

Shaikh, E.A., Roff, J.C., Dowidar, N.M., 1986. Phytoplankton ecology and production in the Red Sea off Jiddah, Saudi Arabia. Mar. Biol. Int. J. Life Ocean. Coast. Waters 92, 405-416. https://doi.org/10.1007/BF00392681.

Siegel, D.A., Behrenfeld, M.J., Maritorena, S., McClain, C.R., Antoine, D., Bailey, S.W., Bontempi, P.S., Boss, E.S., Dierssen, H.M., Doney, S.C., Eplee, R.E., Evans, R.H., Feldman, G.C., Fields, E., Franz, B.A., Kuring, N.A., Mengelt, C., Nelson, N.B., Patt, F.S., Robinson, W.D., Sarmiento, J.L., Swan, C.M., Werdell, P.J., Westberry, T.K., Wilding, J.G., Yoder, J.A., 2013. Regional to global assessments of phytoplankton dynamics from the SeaWiFS mission. Remote Sens. Environ. 135, 77-91. https://doi. org/10.1016/J.RSE.2013.03.025.

Sommer, U., Berninger, U.G., Bottger-Schnack, R., Cornils, A., Hagen, W., Hansen, T., AlNajjar, T., Post, A.F., Schnack-Schiel, S.B., Stibor, H., Stubing, D., Wickham, S., 2002. Grazing during early spring in the Gulf of Aqaba and the northern Red Sea. Mar. Ecol. Ser. 239, 251-261. https://doi.org/10.3354/Meps239251.

Sun, X., Shen, F., Liu, D., Bellerby, R.G., Liu, Y., Tang, R., 2018. In situ and satellite observations of phytoplankton size classes in the entire continental Shelf Sea, China. J. Geophys. Res. Ocean 123 (5), 3523-3544. https://doi.org/10.1029/ 2017JC013651.

Touliabah, H.E., Abu El-Kheir, W.S., Kuchari, M.G., 2010. Phytoplankton composition at Jeddah coast-Red Sea, Saudi Arabia in relation to some ecological factors. JKAU: Sci 148 (632), 1-34. https://doi.org/10.4197/Sci. 22-1.9.

Triantafyllou, G., Yao, F., Petihakis, G., Tsiaras, K.P., Raitsos, D.E., Hoteit, I., 2014. Exploring the Red Sea seasonal ecosystem functioning using a three-dimensional 
biophysical model. J. Geophys. Res. Ocean. 119, 1791-1811. https://doi.org/10. 1002/2013JC009641.

Uitz, J., Claustre, H., Morel, A., Hooker, S.B., 2006. Vertical distribution of phytoplankton communities in open ocean: an assessment based on surface chlorophyll. J. Geophys. Res. Ocean. 111. https://doi.org/10.1029/2005JC003207.

Uitz, J., Stramski, D., Reynolds, R.A., Dubranna, J., 2015. Assessing phytoplankton community composition from hyperspectral measurements of phytoplankton absorption coefficient and remote-sensing reflectance in open-ocean environments. Remote Sens. Environ. 171. https://doi.org/10.1016/j.rse.2015.09.027.

Uitz, J.U., Huot, Y., Bruyant, F., Babin, M., Claustre, H., 2008. Relating phytoplankton photophysiological properties to community structure on large scales. Limnol. Oceanogr. 53, 614-630. https://doi.org/10.4319/lo.2008.53.2.0614.

Vidussi, F., Claustre, H., Manca, B.B., Luchetta, A., Jean-Claude, M., 2001. Phytoplankton pigment distribution in relation to upper thermocline circulation in the eastern
Mediterranean Sea during winter. J. Geophys. Res. 106, 939-956. https://doi.org/10. 1029/1999JC000308.

Ward, B.A., 2015. Temperature-correlated changes in phytoplankton community structure are restricted to polar waters. PLoS One 10 (8), e0135581.

Willmott, C., Matsuura, K., 2005. Advantages of the mean absolute error (MAE) over the root mean square error (RMSE) in assessing average model performance. Clim. Res. 30, 79-82. https://doi.org/10.3354/cr030079.

Zhan, P., Subramanian, A.C., Yao, F., Hoteit, I., 2014. Eddies in the Red Sea: a statistical and dynamical study. J. Geophys. Res. Ocean. 119, 3909-3925. https://doi.org/10. 1002/2013JC009563.

Zhan, P., Krokos, G., Guo, D., Hoteit, I., 2019. Three-dimensional signature of the Red Sea. Eddies and Eddy-induced transport. Geophys. Res. Lett. 46, 2167-2177. https:// doi.org/10.1029/2018GL081387. 